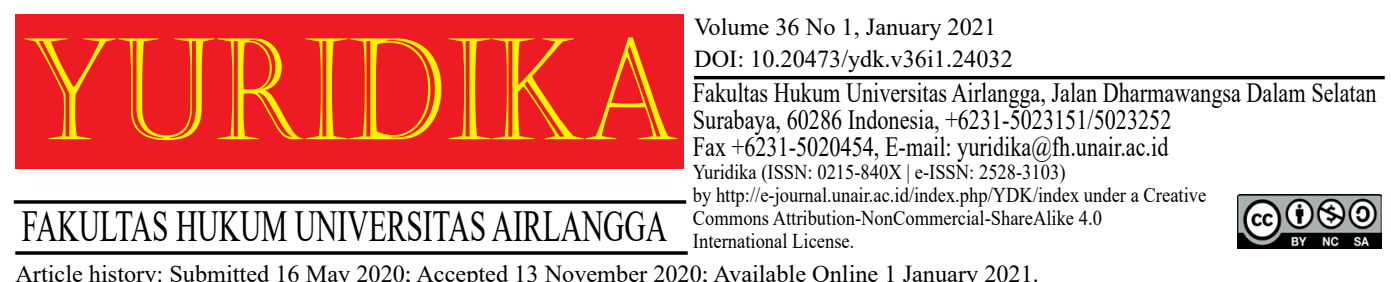

\title{
Protecting Freedom of Expression in Multicultural Societies: Comparing Constitutionalism in Indonesia and Canada
}

\author{
Herlambang P. Wiratraman and Sébastien Lafrance \\ herlambang@fh.unair.ac.id \\ Universitas Airlangga and Public Prosecution Service of Canada
}

\begin{abstract}
This paper explores the similarities and differences in Indonesia and Canada regarding the constitutionally protected freedom of expression. While one may expect that both countries do not have much in common from a general standpoint, both do have several similarities in their approach to the interpretation and application of that freedom. The exercise of freedom of expression is also examined through the spectrum of jurisprudential examples from both countries, more specifically in the context of 'hate speech', 'artistic expression' and 'language expression'.In addition, the social reality of both countries underlying the freedom of expression is uncovered. Further, the limitations imposed in both countries on that fundamental freedom are also discussed. Learning from the exercise that consisted in this paper to compare relevant laws of two countries, and despite the differences between their respective legal traditions, this study argues that freedom of expression, in two different countries such as Indonesia and Canada, can play a more effective role in a society with a multicultural character that complies with the rule of law.
\end{abstract}

Keywords: Freedom of Expression; Multiculturalism; Constitutionalism; Indonesia; Canada.

\section{Introduction}

With the COVID-19 crisis, various legal experts are warning against the threat to freedom of expression. ${ }^{1}$ In 2019, "forty-four people died [in Indonesia] for the cause of freedom of expression". ${ }^{2}$ In the same year, in Canada, the editor

\footnotetext{
1 United Nations Human Rights - Office of the High Commissioner, 'COVID-19: Governments Must Promote and Protect Access to and Free Flow of Information during Pandemic - International Experts' (19 March 2020).

2 Amalinda Savirani, Post-Election Politics in Indonesia: Between Economic Growth and Increased Islamic Conservatism' in Southeast Asian Affairs (Malcolm Cook and Daljit Singh ed, 2020).[147].
} 
and publisher of a community newspaper were found guilty of 'hate speech'. ${ }^{3}$ Even though the struggle for freedom of expression is "as old as civilization itself", these recent events alone make the topic of freedom of expression in Indonesia and Canada incredibly relevant nowadays.

At first glance, comparing the constitutionally protected freedom of expression in Indonesia and Canada, beyond comparing their respective basic State structure ${ }^{5}$ and also because "[ $\left.\mathrm{t}\right]$ he protection of freedom of expression across the world is premised on a similar set of reasons". ${ }^{6}$ Canada and Indonesia have similarity on plural ethnicities. Canada has more than 200 languages from various world ethnicities spoken on its territory, but it has two official languages. While the number of regional languages in Indonesia recorded by the Language Development Agency of the Ministry of Education and Culture reaches 652 regional languages. ${ }^{7}$

\section{Constitutional Rights and Freedoms Frameworks}

A. Indonesia

Indonesia is the most populous country with the Muslim majority in the world where "around 88 percent call themselves Muslims", ${ }^{8}$ whereas it constitutes a tad

3 Section 319(2) of the Criminal Code of Canada They were charged for and were found guilty of two counts of wilful promotion of hatred against an identifiable group - Jews and women.; $R v$ Sears, 2019 ONCJ 104.

4 Kabir Duggal and Shreyas Sridhar, 'Reconciling Freedom of Expression and Flag Desecration: A Comparative Study’ (2006) 2 Hanse L Rev.[142].

5 Simon Butt, 'The Indonesian Constitutional Court: Reconfiguring Decentralization for Better or Worse?' (2019) 14 Asian Journal of Comparative Law.[149]. 'Indonesia is divided into provinces (propinsi); and provinces are divided into counties (kabupaten or 'regencies') and cities (kota), which are the same tier of government". In Canada, there are ten provinces and three territories.

6 Caroline Reid, 'Freedom of Expression, Commercial Expression and Tobacco in Canada' (2008) 39 Victoria U Wellington L Rev.[347].

7 Tirto, 'Jumlah Bahasa Daerah Di Indonesia Mencapai 652' (16 August 2018, 2018) $<$ https://tirto.id/jumlah-bahasa-daerah-di-indonesia-mencapai-652-pada-2018-cSQY> accessed 20 August 2020.

8 Simon Butt, 'Islam, the State and the Constitutional Court in Indonesia' (2010) 19 Pacific Rim Law and Policy Journal.[279].; "87,2\%" in 2020 according to Martin Russell, Political Institutions in Indonesia: Democracy, decentralization, diversity, Briefing, January 20, 2020, 5. 
more than $3 \%$ of the population in Canada. ${ }^{9}$ Because Indonesia is not "an entirely secular state", ${ }^{10}$ religion, or at least how it is understood in the eyes of the law, had an impact on how human rights were modeled $^{11}$ and in turn, how these rights may have been interpreted by the courts, however this would be with the caveat that "the Indonesian state has limited the formal position of Islamic law within the national legal system". ${ }^{12}$ Religion definitely had and still has nowadays an influence on the scope of freedom of expression in Indonesia, basically because this country has 'Pancasila' as its "official philosophical foundation". ${ }^{13}$ For example, ${ }^{14}$

"[In] April 2010, the Indonesian Constitutional Court rejected challenges to Indonesia's blasphemy and heresy law, although the Court did recognize that the legislation in question needed reform. In many countries, however, while such legislation is still extant, it is seldom applied. In Canada, in 1990 case involving holocaust denial, the Supreme Court upheld ... the constitutionality of Section 319(2) of Canada's criminal code, which aimed at suppressing the willful promotion of hatred against identifiable groups".

'Pancasila' ${ }^{15}$ consists, by definition, ${ }^{16}$ of five principles, ${ }^{17}$ that are unique as a whole to Indonesia, and that are inseparable and interrelated. One of those principles is

\footnotetext{
Canada Population' (2020) <https://worldpopulationreview.com/countries/canadapopulation $>$ accessed 18 May 2020. "According to the 2011 National Household Survey, the last census data collected, 3.2\% [of Canadians] were Muslim. There are about 1,053,945 Muslims in Canada".

${ }^{10}$ Simon Butt, 'Islam, the State and the Constitutional Court in Indonesia' (2010) (n 8).[281]. For example, "Dian Shah and Herlambang Wiratraman observe, the most contentious issue debated in 1945 while the constitution was being made was whether Islam should be the religious basis of the state in Indonesia": Jaclyn L. Neo and Bui Ngoc Son, Pluralist Constitutions in the Southeast Asian Content' in Jaclyn L. Neo and Bui Ngoc Son (Eds), Pluralist Constitutions in Southeast Asia (Hart Publishing 2019).[16].

${ }^{11}$ See Articles 28E, 28I(1) and 29 of the Indonesian Constitution

12 Simon Butt, 'Islam, the State and the Constitutional Court in Indonesia' (2010) (n 8).[281].

13 ibid.[70].

14 Javier Martínez-Torrón and W. Cole Durham, 'Religion and the Secular State' in Karen B. Brown and David V. Snyder (ed), General Reports of the XVIIIth Congress of the International Academy of Comparative Law (Springer 2012). [27]. The Blasphemy Law Case (2010) is also discussed more recently in more detail in Simon Butt, The Constitutional Court and Democracy in Indonesia (Brill 2015).[98].

${ }^{15}$ Michael Morfit, 'Pancasila: The Indonesian State Ideology According to the New Order Government' (1981) 21 Asian Survey.[840-841].

16 'Pancasila' comprises two Old Javanese words originally derived from Sanskrit "pañca" ("five") and "sīla" ("principles").

${ }^{17}$ Costantinus Fatlolon, 'Pancasila Democracy and the Play of the Good' (2016) 3 Filocracia. [73]., namely Indonesian nationalism; internationalism or humanitarianism; unanimous decision or democracy; social welfare; and belief in God.
} 
the belief in God. ${ }^{18}$ In addition to that unique feature, its constitution contains an extensive list of human rights, ${ }^{19}$ including the freedom of expression. ${ }^{20}$

\section{B. Canada}

Following the repatriation of the constitution, ${ }^{21}$ Canada adopted in 1982, ${ }^{22}$ the Canadian Charter of Rights and Freedoms ${ }^{23}$ [hereinafter 'Charter'] that enshrined fundamental rights and freedoms in the Canadian Constitution, including the freedom of expression. ${ }^{24}$ Canada is "a federation [where] sovereignty is divided between different levels of government, with some jurisdictions shared and others exclusive to one of the different orders of government" ${ }^{25}$ The existence of federal (national) and provincial levels of government involves the existence of the freedom of expression in the provincial legislations. ${ }^{26}$ However, the Charter "applies to both provincial and federal governments" ${ }^{27}$ where its scope applies

18 'Also Provided by Article 29 of the Constitution of the Republic of Indonesia (Last Amended 2002) [Hereinafter “Indonesian Constitution"]' (1945) <https://www.refworld.org/ docid/46af43f12.html > accessed 19 May 2020.

19 Tim Lindsey and Simon Butt, Indonesian Law (Oxford University Press 2018).[22]. namely Articles $28 \mathrm{~A}$ to $\mathrm{J}$.

${ }^{20}$ Articles 28 and 28E(3) Indonesian Constitution.

${ }^{21}$ John M. Evans, 'Current Constitutional Issues in Canada' (2013) 51 Duq. L. Rev.[327].

22 Rosalie Silberman Abella, 'Freedom of Expression or Freedom from Hate: A Canadian Perspective' (2018) 40 Cardozo L Rev.[512]. She is a puisne judge of the Supreme Court of Canada since 2004.

${ }^{23}$ Canadian Charter of Rights and Freedoms, Part I of the Constitution Act, 1982, being Schedule B to the Canada Act, 1982 (UK), 1982 c1 [hereinafter 'Charter'].

${ }^{24}$ Section 2(b) Charter

${ }^{25}$ François Boucher, 'Deep Diversity and Multinational Federalism in Canada', Students' Best Papers, Summer University, Institute of Federalism, Fribourg, Switzerland' (2008) <https:// www.academia.edu/6780444/Deep_diversity_and_multinational_federalism_in_Canada $>$ accessed 19 May 2020.[8].

${ }^{26}$ Kent Roach and David Schneiderman, 'Freedom of Expression in Canada. Canadian Charter of Rights and Freedoms' (2013) 61 S.C.L.R. (2d).[474]. For example, "Most Canadian [federal and provincial] human rights laws prohibit publishing or displaying material that expresses an intention to discriminate, implies discrimination, or intends to incite others to discriminate": Julian Walker, 'Hate Speech and Freedom of Expression: Legal Boundaries in Canada, Legal and Social Affairs Division, Parliamentary Information and Research Service' Publication No. 2018-25E (29 June 2018).[2].

27 Alan Borovoy, [et.,al], 'Language As Violence v. Freedom of Expression: Canadian and American Perspectives on Group Defamation' (1988) 37 Buff L Rev.[337] (italics added); this distinguishes it from its predecessor, "the Canadian Bill of Rights [that] recognized that freedom of 
to governmental action and "is narrowly drawn by s. 32 of the Charter". ${ }^{28}$ As Julian Walker noted, "Although there is some diversity among human rights laws in Canada ... the provisions in different jurisdictions largely achieve similar purposes, despite using different language". ${ }^{29}$ The enactment of the Charter "alter[ed] the principle of parliamentary supremacy and empowers the judiciary to protect individual rights against what it finds to be improper governmental interference". ${ }^{30}$ In short, "With the adoption of the Charter, Canada became a constitutional democracy" 31 where the "notwithstanding clause' ${ }^{32}$ is described, by some commentators, as a "respite from judicial supremacy". ${ }^{33}$

For Canadians, the Charter "is seen as important to Canadian identity by more people than is the national anthem or the flag". ${ }^{34}$ More than a legal instrument, the Charter would be for Canadians what 'Pancasila' represents for Indonesians, a symbol of their identity. However, even though freedom of religion is protected in Canada by the Charter, ${ }^{35}$ "the State is in no position to be, nor should it become, the

speech was a fundamental right, but it was merely a statutory instrument - not part of the Constitution - and did not apply to provincial laws": Elizabeth L. McNaughton and Christopher M. Goodridge, 'The Canadian Approach to Freedom of Expression and the Regulation of Food and Drug Advertising' (2003) 58 Food \& Drug LJ.[524].

28 Erik S Knutsen, 'Techno-Neutrality of Freedom of Expression in New Media beyond the Internet: Solutions for the United States and Canada' (2001) 8 UCLA Ent L Rev.[113] (italics added).

29 Julian Walker (n 26).[8-9].

${ }^{30}$ Robert A Sedler, 'The Constitutional Protection of Freedom of Religion, Expression, and Association in Canada and the United States: A Comparative Analysis' (1988) 20 Case W Res J Int'l L.[578].

31 Jacob Weinrib, 'What Is the Purpose of Freedom of Expression?' (2009) 67 U Toronto Fac L Rev.[172].

32 Jean Leclair, 'Canada's Unfathomable Unwritten Constitutional Principles' (2002) 27 Queen's L.J.[429]: “Section 33 allows a legislature to enact laws that will apply 'notwithstanding a provision included in section 2 or sections 7 to 15' of the Charter", which includes rights and freedoms such as the freedom of expression.

${ }^{33}$ Grant Huscroft, 'The Constitutional and Cultural Underpinnings of Freedom of Expression: Lessons from the United States and Canada' (2006) 25 U Queensland LJ.[182-183], footnote 8. These issues are discussed more in length, for example, in Shruti Bedi and Sébastien Lafrance, The Justice in Judicial Activism: Jurisprudence of Rights and Freedoms in India and Canada' in Lokendra Malik and Prof. Yogesh P. Singh, Working of the Supreme Court of India: Issues and Challenges (Tentative Title) (Springer Publisher 2020).

34 Centre for Research and Information on Canada, The Charter: Dividing or Uniting Canadians? (2003).[6].

35 Section 2(a) Charter. 
arbiter of religious dogma". ${ }^{36}$ It did not stop, however, the Parliament of Canada to pass a non-binding motion in 2017 , that was not meant, however, to become a law, which called on the Government of Canada to condemn Islamophobia in Canada. Some people, including a Member of Parliament, have accused that motion of going against free speech and leading to "blasphemy laws". ${ }^{37}$ More recently, the Quebec ${ }^{38}$ legislature relied on June 16, 2019 on the 'notwithstanding clause' of the Charter, "to suspend, with regards to the Act respecting the laicity (secularism) of the State that it was passing, all constitutional rights and freedoms which this section permits". ${ }^{39}$ Thus, do Indonesia and Canada stand on two opposite, irreconcilable sides when it comes to the application and interpretation of the freedom of expression?.

\section{Why Compare Freedom of Expression in Indonesia and Canada?}

Why examining and comparing the freedom of expression in Indonesia and Canada? ${ }^{40}$ As pointed out by Daniel Mockle, "the elements that form Canada's political, legal and social identity could easily be compared with other similar characteristics found on several continents". ${ }^{41}$ Therefore, in spite of their sociocultural differences, this article submits that it is possible and also fruitful to

${ }^{36}$ Syndicat Northcrest $v$ Amselem, [2004] 2 SCR 551, para 50, recalled more recently by the same court, the Supreme Court of Canada, in Law Society of British Columbia v Trinity Western University, [2018] 2 SCR 293, para 333 (Côté and Brown JJ, dissenting.

37 Kathleen Harris, 'Liberal MP's Anti-Islamophobia Motion Set for Debate on Wednesday' (February 9, 2019) <https://www.cbc.ca/news/politics/m103-islamophobia-khalid-motion-1.3972194 CBC News> accessed 18 May 2020.

${ }^{38}$ One of the ten provinces of Canada.

39 Maxime St-Hilaire, 'Are Quebec and Canada Having a "Schmittian" (or Iheringian) Moment?' (Int'l J. Const. L. Blog, May 6, 2020) <http://www.iconnectblog.com/2020/05/arequebec-and-canada-having-a-schmittian-or-iheringian-moment> accessed 18 May 2020.

${ }^{40}$ As a former clerk (2010-2011) to Justice Marie Deschamps of the Supreme Court of Canada (puisne judge from 2002 to 2012), I, Sébastien Lafrance, feel the need to mention that I share the following views expressed by Kent Roach, In The Supreme Court on Trial: Judicial Activism or Democratic Dialogue (Irwin Law 2001).IX: “As a former clerk to Justice Bertha Wilson, I might be thought by some to be an apologist for the work of the Court. ... I do not doubt that my prior experiences influence the views expressed in the book, but ask only that they be considered and judged on their own merits ... I write this book ... as an academic interested in ... the Canadian Charter of Rights and Freedoms."

41 Daniel Mockle, 'La Justice Constitutionnelle Face Au Mouvement Conservateur: La Cour Suprême Du Canada et Le Gouvernement Harper (2006-2015)' [Constitutional Justice Facing the Conservative Movement: The Supreme Court of Canada and the Harper Government] (2017) 58 C. De'. 
compare fundamental rights and freedoms between Indonesia and Canada, and more specifically the freedom of expression, without necessarily comparing 'oranges with apples', while keeping in mind that "[b]y its very nature a constitutional charter of rights and freedoms must use general language which is capable of development and adaptation by the courts". ${ }^{42}$ Because the nature itself of a constitutional legal document that protects rights and freedoms would obviously be too broad to constitute on its own the sole basis to justify the proposed comparison, which could basically apply to any set of countries in the world that share "similar characteristics", this article examines if there is more.

In fact, there is more. Both countries also share almost unique features that matter in the study of the freedom of expression. For example, they are among the few countries in the world that "adhere to multiculturalism and to a large extent have included this principle of doctrine in their state ideology or even in their constitution" ${ }^{43}$ and Canada was the first country to recognize it in its constitution. ${ }^{44}$ In Indonesia, Bhinneka Tunggal Ika ('Unity in Diversity') is one the principles included in the 'Pancasila'. In Canada, section 27, which is the section that provides for multiculturalism in the Charter, ${ }^{45}$ "is particularly important when courts are required to balance the freedom of expression", for example, "of hate propagandists against the multiculturalism ideal, especially when read with the powerful equality provision". ${ }^{46}$ History has gone a long way to evolve in that direction. For example, former Prime Minister John A. Macdonald declared in 1887 that "[ $\mathrm{t}$ ] he great aim of our civilization has been to do away with the tribal system and assimilate the Indian

${ }^{42} R v$ Therens, [1985] 1 SCR 613, [para 48].

43 Gary F. Bell, 'Multiculturalism in Law Is Legal Pluralism - Lessons from Indonesia, Singapore and Canada' [2006] Singapore Journal of Legal Studies.[315].(italics added); ibid.[315]. Footnote 2: Canada adopted a multicultural policy in 1971. Since 1982, article 27 of the [Charter] states that: "This Charter shall be interpreted in a manner consistent with the preservation and enhancement of the multicultural heritage of Canadians." In 1985, Canada adopted the Canadian

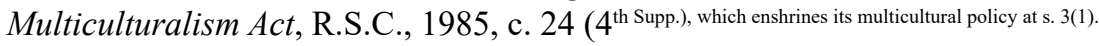

${ }^{44}$ Dominique Clement Will Silver and Dr. Daniel Trottier, 'The Evolution of Human Rights in Canada' (2012).[31].

${ }^{45}$ Section 27 Charter.

46 Alan Borovoy, [et.al.] (n 27).[347]. 
people in all respects". ${ }^{47}$ Today, such a declaration would not go far in Canada but to court. Indeed, "The Right Honourable Stephen Harper, P.C. in the House of Commons acknowledged [in 2008] the harm that resulted from that official policy of Canada and that the assimilation of Indigenous people was offensive"48 and "[t] he word assimilate has taken on a new meaning within [Canada]" ${ }^{49}$ The actual Prime Minister of Canada, Justin Trudeau, also apologized, for example, to the Inuit people for the federal policy on tuberculosis in the mid-20th century. ${ }^{50}$

In Indonesia, conceptually, the idea of freedom of expression has been introduced since the first constitution in $1945^{51}$ and " $\mathrm{t}$ ] he formulation of freedom of expression became extensive and more progressive since the second constitution amendment in 2000". ${ }^{52}$ Likewise, Canada has also adopted since its foundational Charter cases "a generous interpretation of the rights [this legal instrument] established". ${ }^{53}$ The Supreme Court of Canada ${ }^{54}$ [hereinafter 'Court'] relied early after the adoption of the Charter on the metaphor of the "living tree" 55 to justify that the Charter is "capable of growth and expansion". ${ }^{56}$ It will be interesting to compare, for example, how this "extensive and progressive" interpretation in Indonesia, in one hand, and this "generous" interpretation in Canada, in the other hand, unfolded throughout the jurisprudence of the highest courts of these two countries, oftentimes on similar issues.

\footnotetext{
${ }^{47}$ Alan C. Cairns, Citizens Plus and the Canadian State (UBC Press 2000)., note 12; Troller v Manitoba Public Insurance Corporation, 2019 MBQB 157., para 105: "The assimilation of Aboriginal people was the official policy of the Government of Canada

${ }^{48}$ Troller v Manitoba Public Insurance Corporation. ibid.[para 42].

49 Troller v. Manitoba Public Insurance Corporation (n 48). [para 113].

50 Canadian Broadcasting Corporation (CBC), "Trudeau Apologizes for "Colonial," "Purposeful” Mistreatment of Inuit with Tuberculosis' (March 8, 2019) <https:/www.cbc.ca/news/ canada/north/trudeau-apology-tuberculosis-iqaluit-1.5047805.>.

${ }^{51}$ Herlambang P. Wiratraman, 'In Search of Constitutionality: Freedom of Expression and Indonesia’s Anti Pornography Law’ (2012) 20 Yuridika.[113].

52 ibid.[114].

${ }_{53}$ Rosalie Silberman Abella (n 22).[513].

${ }^{54}$ Luc Huppé, Le Régime Juridique Du Pouvoir Judiciaire' [The Legal Regime of Judicial Power] (Wilson \& Lafleur 2000).[3][translated from French by Sébastien Lafrance]: "The Supreme Court of Canada is the only court in the country to have jurisdiction over all of Canada, in all areas of law."

${ }_{55}$ For example, Hunter et al v Southam Inc, [1984] 2 SCR 145, 155-156.

${ }^{56}$ Rosalie Silberman Abella (n 22).[514].
} 
However, Randall Peerenboom observes, "Countries in the process of consolidating democracy such as .... Indonesia are all struggling with central constitutional issues involving ... fundamental rights. ... in most of these countries the legal system remains weak, failing short of basic thin rule of law requirements". ${ }^{57}$ Indeed. ${ }^{58}$

"Indonesia is a Negara Hukum - a country that observes 'the rule of law' ... The Negara Hukum is one of Indonesia's most contentious legal concepts. ... the concept of Negara Hukum equated with all 'versions' of the rule of law, both 'thick' and 'thin'. On one extreme are views that Negara Hukum encompasses the Western concept of the 'rule of law', including its democracy and human rights components. On the other is a much more limited version of rule by law, with no guarantees against authoritarianism”.

In addition, "Unlike the U.S. Constitution, the Charter contains an express limitation to freedom of expression set out in section 1". ${ }^{59}$ As Grant Huscroft noted, "It is often assumed that ... the absence of a 'reasonable limits' clause from the U.S. Bill of Rights explains the different outcomes in American and Canadian freedom of expression cases". ${ }^{60}$ Further, the same author recalled that "[t]he outcome of freedom of expression cases in the United States and Canada does not always differ [and that in] some cases the Court has interpreted the guarantee of freedom of expression as affording greater protection to freedom of expression than the First Amendment". ${ }^{61}$

\footnotetext{
${ }^{57}$ Randall Peerenboom, 'Human Rights and Rule of Law: What's the Relationship' (2005) 36 Geo J Int'l L.[826].

${ }^{58}$ Simon Butt, 'The Indonesian Constitutional Court: Implying Rights from the "Rule of Law" in Rosalind Dixon, Adrienne Stone (Eds.)', The Invisible Constitution in Comparative Perspective (pp. 298-319) (Cambridge University Press 2018).[301, 308-309].

${ }^{59}$ Elizabeth L. McNaughton and Christopher M. Goodridge (n 27).[524].

${ }^{60}$ Grant Huscroft (n 33).[188-189].

${ }^{61}$ ibid. 183 and 190; see also Erik S Knutsen (n 28) ; Abella Rosalie Silberman Abella (n 22).[519]: "in the Canadian approach, the key is the nature of the speech and its relationship to the values underlying freedom of expression. ... the U.S. Supreme Court focused on the need to ensure "that we do not stifle public debate"; Hin-Yan Liu, 'The Constitutional Right to Express Hatred: A Comparative Analysis' (2009) 1 King's Student Law Review.[6]: "The position adopted in the United States [on hate speech] is markedly different than those taken by other liberal democracies such as Canada and Germany"; Maya Hertig Randall, 'Freedom of Expression in the Internet' (2016) 26 Swiss Rev Int'l \& Eur L.[251-252]: "European and Canadian Courts generally adopt a flexible, contextual balancing approach, whilst the U.S. Supreme Court favours a rules-oriented approach based on distinctions between various categories of speech and the purpose of the governmental measure."; Alan Borovoy,[et.,al.] (n 27).[103].
} 
While it is true that "Canada, like most modern constitutions, has a clause permitting reasonable limitations on the right if those limits are justified and proportional", ${ }^{62}$ the interest to compare specifically the Indonesian limitation clause to fundamental rights ${ }^{63}$ with the Canadian clause ${ }^{64}$ lies, among other reasons, in the fact that the so-called Indonesian 'non-derogable' rights ${ }^{65}$ are potentially subject to limitations. ${ }^{66}$ The Charter does not include such a category of rights, at least that is qualified so. The Indonesian limitation clause is provided by Article 28J(2) of the Constitution, and includes "four elements to limit rights or freedom, which are morality, religious values, security, and public order" ${ }^{67}$ whereas, in Canada, the rights and freedoms guaranteed by the Charter are, pursuant to its section 1, 'subject only to such reasonable limits prescribed by law as can be demonstrably justified in a free and democratic society' to determine whether the challenged restriction on that right is justifiable. ${ }^{68}$

The Indonesian Constitutional Court, “one of Indonesia's newest judicial institutions", ${ }^{69}$ explained summarily the Indonesian limitation clause in the following terms: "even the human rights are limited by law, which aims to solely guarantee recognition and respect to rights and obligations of others, and to fulfil justice, based on the moral and religious value considerations, and security and public order in a

${ }^{62}$ Rosalie Silberman Abella (n 22).[518]; see also Patrick J. Monahan and Byron Shaw, Constitutional Law (4th edn, Irwin Law 2013).[436] : "The Charter ... contains a general limitation clause providing that the rights and freedoms protected by the Charter can be limited in appropriate circumstances."

${ }^{63}$ Article 28J(2) of the Indonesian Constitution; see also Herlambang P. Wiratraman, 'In Search of Constitutionality: Freedom of Expression and Indonesia's Anti Pornography Law'(2012) (n 51).[114].

${ }^{64}$ Section 1 of the Charter; see $R v$ Oakes, [1986] 1 SCR 103, which created what is called the "Oakes test" in Canadian constitutional law. This legal test applies, explained summarily, in cases where there is a Charter breach of a right or a freedom in order to determine whether such a breach could be "justified in a free and democratic society".

${ }^{65}$ Section 28I(1) Indonesian Constitution.

${ }^{66}$ Tim Lindsey and Simon Butt (2018) (n 19).[22].

${ }^{67}$ Herlambang P. Wiratraman, 'In Search of Constitutionality: Freedom of Expression and Indonesia’s Anti Pornography Law' (n 51).[114].

${ }^{68}$ Robert A Sedler (n 30).[580].

69 Prayekti Murharjanti, 'The Effectiveness of the Constitutionalisation of Environmental Rights in Indonesia: Judicial Application and Government Compliance' (University of Sydney, Australia 2019).[42]: it was created in 2003. 
democratic society" ${ }^{70}$ In some cases, the Indonesian Constitutional Court "might choose to reconstruct a statute to ensure its compliance with the constitutional provision, postponed the enactment of decisions or give orders to lawmakers". ${ }^{71}$ This is not an approach that is necessarily totally foreign ${ }^{72}$ to Canadian courts. ${ }^{73}$

The authors hope that the comparison of the freedom of expression in Indonesia and Canada could eventually assist "to understand better, and to improve, [each other's] national law"74 in the context where, learning from past constitutionalism debates showed freedom of expression has undergone such long historical and political processes of power [in Indonesia]". ${ }^{75}$

\section{Definition and Scope}

A. Indonesia

In Indonesia, "the right to freedom of expression is regulated both in the Constitutional law and also by several laws and regulations". ${ }^{76}$ It was constitutionalized by its inclusion in the Constitution of 1945 under Article 28,

70 Constitutional Court Decision 99/PUU-X/2012 reviewing Law No 12 of 1992 on the Horticulture System.

${ }^{71}$ Bisariyadi, 'Atypical Rulings of the Indonesian Constitutional Court' (2016) 2 Hasanuddin Law Review.[225].

${ }^{72}$ In $R$ v Zundel, [1992] 2 SCR 731 . [513], McLachlin J., as she then was, writing for the majority of the Court, warned against the dissenting judge's views that, in her opinion, was "[ $\mathrm{t}]$ o convert s. 181 [of the Criminal Code of Canada] into a provision directed at encouraging racial harmony [, which] is to go beyond any permissible shift in emphasis and effectively rewrite the section." (italics added).

73 Robert J. Shape, 'The Supreme Court of Canada in Changing Times' (2003) August 27 Ontario Justice Education Network.[1]: "the Charter has greatly enhanced the power of the courts to influence and decide important and controversial issues of public policy. The courts, in particular, the Supreme Court of Canada, have fully accepted and embraced that mandate. The courts have generously interpreted the rights and freedoms protected by the Charter, and have not hesitated to strike down and occasionally rewrite laws that infringe Charter guarantees." (italics added); see also Shruti Bedi and Sébastien Lafrance (n 33).

${ }^{74}$ Gunter Frankenberg, 'Critical Comparisons Re-Thinking Comparative Law' (1985) 26 Harv. Int'1 L.J.[411, 418], citing R. David and J. Brierley, Major Legal System in the World Today (2nd ed, Free Press 1978).[4].

${ }^{75}$ Herlambang P. Wiratraman, 'Kebebasan Bereskpresi: Penelusuran Pemikiran Dalam Konstitusi Indonesia' (2009) 6 Jurnal Konstitusi.[130] [translated in English by Sébastien Lafrance].

76 L.I. Nurtjahyo, 'Pembatasan Hak Kebebasan Berekpresi Berdasarkan Isu Ketertiban Umum: Kajian Atas Kovenan, Prinsip-Prinsip, Dan Produk Hukum Nasional', in Kebebasan Berekspresi di Indonesia - Hukum, Dinamika, Masalah, dan Tantangannya (Lembaga Studi dan Advokasi Masyarakat (ELSAM) 2019).[84]. 
which provides, "Freedom of association and assembly, of expressing thoughts and of issuing writing and the like, shall be prescribed by statute." However, the terms "prescribed by statute" in that constitutional provision proved problematic in practice. Indeed, situations adverse to freedom of expression happened under all regimes in Indonesia since the independence. ${ }^{77}$ These 'several laws and regulations' mentioned above, on several occasions, caused interpretation issues with respect to the scope of the freedom of expression in Indonesia, mostly because these laws and regulations were often used to silence criticism, and not to make, as it should be expected, various kinds of expression blossom in the nation. For example, Law No. 9 of 1998 on Freedom of Opinion in Public Sphere that governs the form, procedure and manner of public opinion, and which provides a flexible interpretation so much so that it could be arbitrarily misused by authorities.

An example remains the best way to understand some of the issues in relation to the fundamental freedom in Indonesia. Following the incorporation of rights to freedom of information and expression in the Indonesian Constitution, the government enacted two related laws, Law No 14 of 2008 concerning Public Information Openness and Law No 11 of 2008 on Electronic Information and Transaction (hereinafter 'EIT'). Cyber-defamation is provided in the EIT under Article 27(3). It reads: "Any person who knowingly and without authority distributes and/or transmits and/or causes to be accessible Electronic Information and/or Electronic Records with contents of affronts and/or defamation.” The EIT provisions on cyberdefamation became controversial because, among other reasons, this criminal offense provides for a maximum length of imprisonment of more than five years, i.e. six years pursuant to Article 45 EIT. Its use could also push State agents in Indonesia to seek detention, and then potentially become, depending on the allegations made, a serious threat to the freedom of expression and the press. In a nutshell, this controversy was triggered by the fact that restrictions imposed

\footnotetext{
77 Adriaan Bedner, Administrative Courts in Indonesia: A Socio-Legal Study (Martinus Nijhoff 2001).; Herlambang P. Wiratraman, Press Freedom, Law and Politics in Indonesia. A SocioLegal Study (EM Meijers Institute, Wohrmann 2014).
} 
on the right to freedom of expression, under Articles 27, 28 and 29 EIT, do not include protection of human rights. ${ }^{78}$ Therefore, many voices that may be critical or different from the State's narrative may end up being silenced via the application of those provisions.

The EIT had also a direct practical substantial impact on the exercise of the freedom of expression for Indonesian citizens soon after its adoption in 2008. For example, the Southeast Asian Freedom of Expression Network (SAFEnet), a nonprofit organization that is focused on freedom of expression, recorded, at the very least, 271 case reports involving the EIT since $2008 .{ }^{79}$ Most of the time, complainants base their allegations on Article 27(1) (containing content that violates decency), Article 27(3) (defamation), Article 28(2) (broadcasting hatred), and Article 29 (threat of violence) of the EIT. Anton Muhajir from SAFEnet reported that there were at least about 3100 cases that involved the EIT throughout $2019 .{ }^{80}$

This extensive reliance on the EIT may make one wonder about the legitimacy of all these cases, which, in turn, calls into question the possibility for Indonesians to exercise freely their freedom of expression, at least when considering that it is a fundamental freedom protected by the 1945 Constitution. Thus, civilians filed a petition challenging the constitutionality of Article 27(3) in the Indonesian Constitutional Court. According to the petitioners, this Article does not take into account the rule of law, ${ }^{81}$ which requires a provision to be clear, and fairly enforced. It is also the authors' view that the lack of clarity of this Article may eventually lead to potential abuses, and then, that it weakens the application of the rule of law in Indonesia, namely the application of the principles of predictability and transparency. It is also fair to submit that Article 27(3) encroaches the principle

78 Herlambang P. Wiratraman, 'Freedom of Expression, Law and Politics in Indonesia' in Azmi Sharom and Magdalen Spooner (ed), Human Rights and Democracy in Indonesia and Malaysia (SIRDC and SEAHRN 2019).[61].

79 Tirto, 'Banjir Kasus Pasal Karet UU ITE Sepanjang 2019 [A Flood of ETI Cases Throughout 2019]' (27 December, 2019) < https://tirto.id/banjir-kasus-pasal-karet-uu-ite-sepanjang2019-eo4V> accessed 30 June 2020. [translated from Indonesian by Sébastien Lafrance].

${ }^{80} \mathrm{ibid}$.

${ }^{81}$ Adriaan Bedner, 'An Elementary Approach to the Rule of Law' (2010) 2 Hague Journal on the Rule of Law.[48-74]. 
of lex certa (legal certainty) because its wording is not clear enough, especially regarding the scope of the criminal acts that it covers. In addition, heavy criminal sanctions such as six years' imprisonment could result, as a collateral effect, in the creation of a culture of improper self-censorship on the part of the media for whom the threat of a jail sentence, more severe than those stipulated in the Criminal Code, could be used to indirectly or directly silence them.

Conversely, the judges of the Indonesian Constitutional Court stated that Article 27(3) merely constituted a limitation to the freedom of expression, that it was not infringing the constitution. The limitations of the freedom of expression under the EIT are regulated by the State to avoid hindering fundamental rights to seek, obtain, possess, store, and convey information, to guarantee freedom from threats against individual or family dignity, and also to prevent degradation of human dignity. ${ }^{82}$ Regarding the human rights issues, the judges of that court considered that the EIT was important to secure and protect the freedom of expression. They dismissed the petitioners' claims.

Some forms of hate speech in Indonesia are not actually entirely hate speech per se, but they rather involve a dimension that shows some politicization, more specifically in a way that uses religion in order to mobilize supporters and get rid of opponents or those who have been threatening towards certain oligarchic groups of power. In theory, this is what Cherian George calls "hate spin". ${ }^{83}$ Two controversial and well-known cases of this practice, namely the case against the Governor of Jakarta, Basuki Cahaya Purnama or Ahok, and also the case of a housewife in Medan, Meliana.

Ahok was charged with multiple articles, namely Article 156a or Article 156 of the Indonesian Criminal Code, because his statement quoted a letter in the Koran and conveyed it in order to explain that there was no need to worry

${ }^{82}$ Indonesian Constitutional Court Decision Number 2/PUU-VII/2009, 5 May 2009.

${ }^{83}$ Cherian George, Hate Spin: The Manufacture of Religious Offense and Its Threat to Democracy (MIT Press 2016). 
about politicization. However, the prosecutor considered that case against Ahok was proven, i.e. to insult certain groups. He faced imprisonment of up to 4 years. Prosecutors asked that Ahok be given a jail sentence of 1 year with a probation period of 2 years.

Meliana's case was similar. She was charged with blasphemy, which sparked a riot with racial nuances in Tanjung Balai, North Sumatra. She was charged for this offense for communicating with street vendors who had no intention of offending religion. However, the court that he committed such act and was found guilty pursuant to Article 156 and Article 156A of the Indonesian Criminal Code, and a sentence of 18 months in prison was imposed on her. ${ }^{84}$ These cases are, in fact, more related to "hate spin" rather than hate speech, and they certainly reflect how law enforcement could eventually be used in Indonesia. Such challenges imposed on minorities are not surprising. Even though Pancasila recognizes diversity, it is agreed to be the official philosophy of the nation, but, in practice, the application of Pancasila reflects more the interests of the dominant political power. To paraphrase Pranoto, Pancasila has been translated as the role of the state to recognise a limited number of religions. It should not be a surprise when it legitimises and preserves the status quo, especially when the religious grandees use it to urge the state to prosecute religious minorities. ${ }^{85}$

B. Canada

In Canada, the importance of freedom of expression was described in the following terms by the Court, "It is difficult to imagine a guaranteed right more important to a democratic society. Indeed, a democracy cannot exist without the freedom to express new ideas and to put forward opinions about the functioning of public institutions. The concept of free and uninhibited speech permeates all truly democratic societies and institutions". ${ }^{86}$ Freedom of expression, sometimes called

\footnotetext{
${ }^{84}$ Kompas, 'Kronologi Kasus Meiliana Yang Dipenjara Karena Keluhkan Pengeras Suara Azan' (23 August, 2018) <https://regional.kompas.com/read/2018/08/23/15053451/kronologikasus-meiliana-yang-dipenjara-karena-keluhkan-pengeras-suara-azan> accessed 12 August 2020.

${ }^{85}$ Pranoto Iskandar, 'The Pancasila Delusion' (2016) 46 Journal of Contemporary Asia.

${ }^{86}$ Edmonton Journal v Alberta (Attorney General), [1989] 2 SCR 1326, 1336.
} 
freedom of speech, ${ }^{87}$ is constitutionally protected in Canada by section $2(b)$ of the Charter. It reads: "Everyone has the following fundamental freedoms ... freedom of thought, belief, opinion and expression, including freedom of the press and other media of communication".

In its seminal ${ }^{88}$ and classical ${ }^{89}$ case, Irwin Toy Ltd. v. Quebec (Attorney General), the Court stated that "expression" has both a content and a form, and the two can be inextricably connected. Activity is expressive if it attempts to convey a meaning". ${ }^{90}$ It held a "prohibition on advertising directed at children under 13 years of age". ${ }^{91}$ Robin Elliot recalled, "The definition of freedom of expression that emerges from Irwin Toy is any non-violent activity that conveys or attempts to convey a meaning".92 The purposes of the protection afforded by section $2(b)$ of the Charter have been delineated by the Court as follows: ${ }^{93}$

“(1) Seeking and attaining truth is an inherently good activity; (2) participation in social and political decision-making is to be fostered and encouraged; and (3) the diversity in forms of individual self-fulfillment and human flourishing ought to be cultivated in an essentially tolerant, indeed welcoming, environment not only for the sake of those who convey a meaning but also for those to who it is conveyed".

In a nutshell, "There are many arguments for protecting freedom of expression, but all seem to focus on one or a combination of three values: truth, democracy

${ }^{87}$ Adrienne Stone, The Comparative Constitutional Law of Freedom of Expression' in Tom Ginsburg and Rosalind Dixon (Eds), Comparative Constitutional Law (Edward Elgar Publishing 2011).[2]: "There is some variation among the constitutions of the world in the nomination of 'speech', 'expression' and 'communication' as the subjects of constitutional protection."

${ }^{88}$ Chanakya Sethi, 'Beyond Irwin Toy: A New Approach to Freedom of Expression under the Charter' (2012) 17 Appeal: Rev Current L \& L Reform.[26].

${ }^{89}$ Richard Moon, 'Lifestyle Advertising and Classical Freedom of Expression Doctrine' (1991) 36 McGill LJ.[89].

${ }^{90}$ Irwin Toy Ltd $v$ Quebec (Attorney General), [1989] 1 SCR 927. [968] (italics added); Adrienne Stone (n 87).[3]: "A guarantee of freedom of expression, like other rights, has two conceptually distinct elements: 'coverage', which refers to the acts or things to which the principle applies, and 'protection', which refers to the weight of the principle or the level of protection that the right covers on those acts or things".

${ }^{91}$ Kent Roach and David Schneiderman (n 26).[442-443].

92 Robin Elliot, 'Back to Basics: 'A Critical Look at the Irwin Toy Framework for Freedom of Expression' (2011) 15 Rev Const Stud.[210].

${ }_{93}$ Irwin Toy Ltd. v. Quebec (Attorney General), [1989] 1 SCR 927 (n 90).[976-977] ; see also Ford v Quebec, [1988] 2 SCR 712.[765-766]; R v Keegstra, [1990] 3 SCR 697. 
and individual autonomy". ${ }^{44}$ Therefore, John Stuart Mill's marketplace theory ${ }^{95}$ still seems to have "a substantial impact on modern thinking" and on Canadian constitutional law, at least regarding the interpretation of the freedom of expression. Indeed, as Matteo Maciel pointed out, "Both Mill and the [Supreme Court of Canada] set limits unto freedom in the interest of protecting harms ... the right to not be harmed by others". ${ }^{97}$ However, as an author noted, "The marketplace of ideas rationale conflicts with the larger purpose of the Charter framework". 98

The Court defined freedom of expression "so broadly [that] virtually any law that restricts any attempt to convey meaning will violate section $2(b),{ }^{99}$ including for example even physical acts such as "illegally parking a car, so long as it was meant to convey meaning (such as protesting the manner in which parking spots are allocated)". ${ }^{100}$ The judges of the Court turned their mind when they had to consider that freedom to "the most controversial areas, everything from hate speech to obscenity and defamation" 101 as well as political speech, ${ }^{102}$ "perjury, counselling suicide, and creating child pornography", and even "illegal solicitation". ${ }^{103}$ In all these areas the Court circumscribed in each case the definition of freedom of expression but... “without apparent definitional limitations". ${ }^{104}$ In a different context, Pierre-André Côté wrote: "Definitions may be furnished to add a greater measure of precision but the opposite is often the result: "The more words there are, the more words there

\footnotetext{
94 Richard Moon, 'The Social Character of Freedom of Expression' (2009) 2 Amsterdam LF.[43].

95 Uladzislau Belavusau, 'Hate Speech', the Max Planck Encyclopedia of Comparative Constitutional Law (Oxford University Press 2017) : "The most cited book on freedom of expression in Anglo-American constitutional doctrine, John Stuart Mill's 1859 treatise 'On Liberty"'.

${ }_{96}$ Clare F Beckton, 'Freedom of Expression in Canada - How Free' (1983) 13 Man LJ.[586].

${ }^{97}$ Matteo Maciel, J.S. Mill on Hate Speech in the Canadian Context, vol IX (Minneapolis, Minnesota 2016).[90].

98 Jacob Weinrib (n 31).[175].

99 Elizabeth L. McNaughton and Christopher M. Goodridge (n 27).[524].

${ }^{100}$ Kent Roach and David Schneiderman (n 26).[433].

${ }^{101}$ Grant Huscroft (n 33).[187].

${ }^{102}$ Kent Roach and David Schneiderman (n 26).[435].

${ }^{103}$ Reference re ss 193 and 1951(1)(C) of the Criminal Code (Man), [1990] 1 SCR 1123.; Julian Walker (n 26).[3].

${ }^{104}$ Chanakya Sethi (n 88).[21].
} 
are about which doubts may be entertained ". ${ }^{105}$ However, as this article pointed out earlier, "[b]y its very nature a constitutional charter of rights and freedoms must use general language which is capable of development and adaptation by the courts", ${ }^{106}$ which makes it by definition (!), and by analogy with classical music, a perpetual 'Unfinished Symphony'. ${ }^{107}$ Some commentators have been quite critical of the Court's methodology in its interpretation of the freedom of expression: "Canada's unstable freedom of expression tradition"108 and also "[t]he Court's current section 2(b) methodology, including its application of [the limitation clause provided by] section 1, falls short because it lacks a framework within which to concretely apply [a] normative judgment". ${ }^{109}$ As it may be expected, other authors did not reject entirely the Court's methodology. For example, Rosalie Silberman Abella, a sitting judge of the Court, wrote, in an article, "Because finding a breach [of a Charter right or freedom] does not end the analysis, Canadian courts have been willing to take a very broad view of what types of expression qualify for protection under the Charter". ${ }^{110}$ In the same breath, Madam Justice Abella wrote, referring to a decision of the Court"111 that "not all expression is equally worthy of protection", ${ }^{112}$ i.e. when it is determined "whether the individual right implicated by the challenged law or governmental actions comes within the Charter's protection", ${ }^{113}$ e.g. a violent activity would not be protected. Hin-Yan Liu contends regarding Canada's approach to freedom of expression that it provides a "presumptive protection of expression to be limited in narrow categories on strict criteria when it infringes upon conflicting constitutional rights is arguably the best approach; it allows for high levels of speech

\footnotetext{
${ }^{105}$ Pierre-André Côté, The Interpretation of Legislation in Canada Translated and Revised by Steven Sacks (4th ed, Carswell 2011).[68]. (quoting Lord Halsbury, The Laws of England (London: Butterworths, 1907) at ccxvi)

${ }^{106}$ R. v. Therens, [1985] 1 SCR 613 (n 42).

${ }^{107}$ Franz Schubert's Symphony No. 8 in B minor, D 759 commonly known as the Unfinished Symphony.

${ }^{108}$ Kent Roach and David Schneiderman (n 26).[525].

${ }^{109}$ Chanakya Sethi (n 88).[25].

${ }^{110}$ Rosalie Silberman Abella (n 22).[515]. (italics added).

${ }^{111}$ Rocket $v$ Royal College of Dental Surgeons of Ontario, [1990] 2 SCR 232, para 40; see also Edmonton Journal v. Alberta (Attorney General), [1989] 2 SCR 1326, 1336 (n 86).

${ }^{112}$ Rosalie Silberman Abella (n 22).[515] (italics added).

${ }^{113}$ Robert A Sedler (n 30).[580].
} 
protection, but allows limitations when the freedom interferes substantially other rights or constitutional values". ${ }^{114}$

Some commentators recalled that "[t]he Irwin Toy framework was harshly criticized by a number of scholars and counsel" 115 and that "this framework was not designed for, and therefore should not be taken to deal with, all of the different kinds of cases that s. 2(b) has shown itself to be capable of generating", ${ }^{116}$ however the Court "continues to invoke it today". ${ }^{117}$ Therefore, in spite of these serious critics, and also because of the wide range of areas that have been covered by the decisions of the courts and the doctrine regarding freedom of expression in both Indonesia ${ }^{118}$ and Canada, ${ }^{119}$ the authors of this paper had to limit the analysis and the comparison between Indonesia and Canada to some of the most prominent, impactful and recent judicial decisions decided in each country.

\section{Jurisprudential Approach}

A. Indonesia

\section{i. Artistic Expression}

Muhammad Isnur, Head of Advocacy for the Indonesian Legal Aid Foundation (YLBHI), reported recently, in June 2020, that there was an attempt to silence the

\footnotetext{
${ }^{114}$ Hin-Yan Liu (n 61).[20-21].

115 Robin Elliot (n 92).[206].

${ }^{116}$ ibid.[209].

117 ibid.[207].

${ }^{118}$ For example, freedom of the press (see e.g. Herlambang P. Wiratraman, 'Press Freedom, Law and Politics in Indonesia: A Socio-Legal Study' (Leiden University 2004); freedom of speech and the Internet (see e.g. Herlambang P. Wiratraman, 'Does the Revised IT Law Guarantee More Freedom?' (The Jakarta Post, November 24, 2016) < https:/www.thejakartapost.com/academia/2016/11/24/ does-the-revised-it-law-guarantee-more-freedom.html> accessed 27 May 2020.

119 For example, commercial expression (R.J. Sharpe, 'Commercial Expression and the Charter' (1987) 37 U.T.L.J. [229, 230]: “What distinguishes commercial speech from other forms of expression relates directly to the nature and purpose of the message conveyed. A commercial message is one which has as its purpose the proposal of an economic transaction"; RJR-MacDonald Inc v Canada (Attorney General), [1995] 3 SCR 199); defamation (see e.g. $R$ v Lucas, [1998] 1 SCR 439; Hill $v$ Church of Scientology of Toronto, [1995] 2 SCR 1130); freedom of the press (see e.g.Benjamin Oliphant, 'Freedom of the Press as a Discrete Constitutional Guarantee' (2014) 59-2 McGill Law Journal.); academic freedom (see e.g. Linda McKay-Panos, 'Universities and Freedom of Expression: When Should the Charter Apply' (2016) 5 Can J Hum Rts.[59]; Michael Marin, 'Should the Charter Apply to Universities?' (2015) 35:1 NJCL.;Julius H. Grey, 'Freedom of Expression in a Canadian University Context' (1995) 44 U.N.B.L.J.).
} 
critics related to the attacks experienced by a comedian, Bintang Emon. ${ }^{120}$ The attempts to silence the comedian occurred after he criticized, wrapped in comedy, the use of Hydrochloric Acid (HCL) against an investigator of the Corruption Eradication Commission (Komisi Pemberantasan Korupsi also known as 'KPK'), Novel Baswedan. The comedian was harassed through social media; it was a character assassination. Although the case has been reported to the police, there has been no further investigation. Similar cases have also been experienced by journalists and writers. Before that occurrence with that comedian, artistic expression had already repeatedly been targeted by the police in Indonesia, due to communism stigma. For example, in 2015, police officers cancelled the Drama Script Readings and Family Album Discussion: '50 Tahun 1965'. The Indonesian National Police Metro Jaya banned the reading of drama scripts and discussions because the activities carried out was deemed to be related to communism. ${ }^{121}$ In the same vein, and even if it is not recent, the following case is illustrative to show an ongoing reality in Indonesia when it comes to artistic expression and the freedom of expression: in 2015, the projection of 'The Silence' movie in the context of the theme of 1965 on the campus of ISI Yogyakarta and Brawijaya University, Malang, during the Ubud Write Festival was prohibited. Not only were discussions or movies about that theme banned but so were some books, too, ${ }^{122}$ which ban was also based on the same pretext, i.e. the fear of the spread of the teachings of communism.

That fear of the spread of communism was not solely reserved to Indonesia. Indeed, it reached the Supreme Court of Canada in 1957 in the landmark decision

\footnotetext{
${ }^{120}$ Kompas, 'YLBHI: There Are Efforts to Mute Systematic Criticism' (15 June 2020) $<$ https://nasional.kompas.com/read/2020/06/15/20220211/ylbhi-ada-oper-pembamanaman-kritik systematically>.

${ }^{121}$ The Prohibition Letter No B/19811/XII/2015/Datro, signed by the Director of the Jakarta Metro Police Intelligence, Commissioner of Police, Suntana.

${ }^{122}$ Hendri Yulius, "When Books Become Threats: Preserving "Public Order" in Indonesia, Indonesia at Melbourne' (May 23, 2016) < https://indonesiaatmelbourne.unimelb.edu.au/whenbooks-become-threats-preserving-public-order-in-indonesia $>$ accessed 30 June 2020; Herlambang P. Wiratraman, 'Kebebasan Akademik, Neo-Feodalisme Dan Penindasan HAM' in Al Khanif \& Manunggal (ed), Hak Asasi Manusia: Politik, Hukum dan Agama di Indonesia (LKIS 2018).[57].
} 
of Switzman v. Elbling and A.G. of Quebec, ${ }^{123}$ which struck down Quebec's-one of the Canadian provinces-'Padlock Law' (officially called Act to protect the Province Against Communistic Propaganda), law enacted in 1937. The 'Padlock Law' was successfully challenged by Mr. Switzman as a violation of the freedom of speech (then, not constitutionally protected).

In 2010, the Indonesian Constitutional Court discussed the banning of books in the case No. 61320/PUU-VIII/2010. The judges of that court found that the authority to ban books based on Law 16/2004 on the Public Prosecution and also based on Law 4/PNPS/1963 on Securing Printed Materials that Impede Public Order the General Order ${ }^{124}$ was unconstitutional. This was the end of the governmental authority to ban books. In its reasons, the Indonesian Constitutional Court stated, "The seizure of books ... is the same as arbitrary personal property rights that is strictly prohibited by Article $28 \mathrm{H}(4)$ of the 1945 Constitution which states, 'Everyone has the right to own property, personal and proprietary rights shall not be arbitrarily acquired by anyone"".

ii. Hate speech

Hate speech in Indonesia's legal framework originates from the Netherlands Indies' penal code legacy and is known in Dutch as 'haatzaai artikelen', which means 'hatred sowing' or 'hate speech' (menabur kebencian or ungkapan kebencian in Indonesian). The laws on hate speech can be divided in three categories: ${ }^{125}$ the first category addresses hatred expressed 'against the government and State symbols' pursuant to Articles 154 and 155 of the Penal Code (Kitab Undang Undang Hukum Pidana or also called 'KUHP'); the second category is about hatred expressed 'against a person or the public' pursuant to Articles 156 and 157 of the Penal Code; and the third category concerns hate speech expressed via cybermedia pursuant to Article 28(2) of the EIT.

${ }^{123}$ Switzman v Elbling and AG of Quebec, [1957] SCR 285.

${ }^{124}$ Enacted by Law 5/1969 on Statements of Various Presidential Assignments and Presidential Regulations. 78).[171].

${ }^{25}$ Herlambang P. Wiratraman, 'Freedom of Expression, Law and Politics in Indonesia' (n 
At the time of Soeharto's New Order authoritarian regime, hate speech provisions were often used to silence criticism. ${ }^{126}$ After his fall, the 'haatzaai artikelen' were still used, for example in the case of Rakyat Merdeka. This case became somewhat of a cause célèbre because it drew international attention, especially in Muslim countries. The case was about the publication by Rakyat Merdeka of one of the cartoons of the Prophet Muhammad that was originally published in the JyllandsPosten in Denmark. When this was first published in 2005, nothing happened, however it caused an uproar later, and the chief editor of Rakyat Merdeka was prosecuted before the South Jakarta District Court on the basis of contravening Article 156a of the Penal Code. This Article pertains to the misuse or blasphemy of religion. In his plea, titled 'Saya Hanya Jurnalis Biasa, Bukan Penista Agama' (I am an ordinary journalist, not a religion hater), ${ }^{127}$ the chief editor of Rakyat Merdeka pointed out that before the publication of that cartoon, Rakyat Merdeka had modified it to reduce the vulgar aspects of the original version. Still, after many complaints received about it, Rakyat Merdeka explained in February 2006, in 'Kami Tak Bermaksud Ikut Menghina' (We Did Not Intend to Insult Anyone), that it did not have the intention to insult anyone. Nevertheless, about two hundred members of the Muslim fundamentalist vigilante FPI (Front of Defenders of Islam) gathered at the Rakyat Merdeka office while on their way to the Danish Embassy. After the editors gave an explanation to their leaders, the FPI said they would only ask the editors to delete the publication and to also apologize to the public. This agreement was published on the Rakyat Merdeka website. ${ }^{128}$ Rakyat Merdeka had already done it.

The 'haatzaai artikelen' was repealed after the Indonesia Constitutional Court ruled in 2007 in its decision No. 6/PUU-V/2007. That court declared that Articles 154 and 155 of the Penal Code were contrary to the Constitution, and no

\footnotetext{
${ }^{126}$ Ind Govt v Goei Po An (Terompet Masyarakat) (1951); Ind Govt v AJI (Ahmad Taufik, Eko Maryadi, and Danang KW) (1995) ; Ind Govt v Andi Syahputra (Suara Independen) (1996).

${ }^{127}$ The plea was delivered by Teguh Santosa during the second court session, 6 September 2006, in the South Jakarta District Court.

${ }^{128}$ Redaksi dan FPI Sepakat Akhiri Kontroversi [Editorial Board and FPI Agree to End the Controversy], 3 February 2006.[translated from Indonesian by Herlambang P. Wiratraman].
} 
longer binding. That being said, there still seems to be a danger nowadays that the 'haatzaai artikelen' may eventually be 'excavated from their grave' or that they may rise from the ashes. This, for two main reasons: first, the scope of hate speech provided by the Indonesian Penal Code was reinforced by the special rules of the EIT, applicable at least cyber-communications. Indeed, as Article 28(2) EIT Law reads, "It is prohibited that any person knowingly and without any right disseminates information that is intended to evoke feelings of hatred or hostility against an individual and/or particular group based on ethnicity, religion, race and intergroup"; second, during the COVID-19 pandemic, the National Police Commander enacted instructions on how to to handle that pandemic. ${ }^{129}$ The impact of these instructions on civil liberties, all justified under the umbrella of the 'emergency', ${ }^{130}$ could come to life by way of potential threats to the freedom of opinion, and to press freedom of journalists. These threats could take place, for example, should opinions or views of some of the population on this or that issue about the COVID-19 be different than what is reported by the news or the scientists.

iii. Language expression

The issues concerning the freedom of expression, and more specifically the use of a language in Indonesia, are directly impacted by the religious reality of the country because it has, as this article previously noted, the world's largest Muslim population. Two court cases exemplify that reality.

First, the case involving Yusman Roy of the I'tikaf Ngaji Lelaku Boarding School. In 2005, a panel of judges of the Kepanjen District Court in Malang sentenced Yusman Roy to two years in prison because he was found guilty of misuse or blasphemy of religion as provided by Article 156a of the Indonesian

${ }^{129}$ Gen. Idham Azis issued the Decree of the Chief of Police Number: Mak/2/III/2020 concerning Compliance with Government Policy in Handling the Distribution of COVID-19. In addition, Gen. Idham Azis issued a telegram letter (ST/1100/IV/HUK.7.1/2020) signed by Criminal Department of Police, Gen. Commissaries Listyo Sigit Prabowo on behalf of the National Police Chief, on Saturday, April 4, 2020. The telegram letter regulates police obligations in dealing with the pandemic, included critics against the officials.

${ }^{130}$ Herlambang P. Wiratraman, 'Does Indonesian COVID-19 Emergency Law Secure Rule of Law and Human Rights?' (2020) 4 Journal of Southeast Asian Human Rights.[319-320]. 
Penal Code, ${ }^{131}$ for developing the teaching of prayer in two languages, namely Indonesian and Arabic ${ }^{132}$ - because it must only be in Arabic.

Second, the case involving the Minang language application - the fourth largest ethnic group in Indonesia (or also called Minangkabau) - in the Google Play Store, was so seriously criticized that it was forced to stop being available. Irwan Prayitno, the Governor of West Sumatra, wrote to the Indonesian Minister of Communication and Information. He then requested that the application be removed because he considered that it was in conflict with Minangkabau's customs and culture. According to him, the existence of the Minang language Bible application caused trouble, and it became a polemic issue amongst the Minangkabau people. ${ }^{133}$ Of note, the Indonesian Bible Institute had translated the Bible into at least seventy regional languages in Indonesia, including the Minang language. The Governor declared that the ban on the Minang language was related to Minangkabau adat, or local customary law especially of Islamic-Malay tradition in Indonesia, which has the philosophy of 'Adat Basandi Syarak, Syarak Basandi Kitabullah', which is comprised of customs and culture that are attached to the teachings of Islam based on the Koran and Hadith. ${ }^{134}$

\section{B. Canada}

\section{i. Artistic Expression}

Humour is a form of artistic expression. Sometimes humour needs to be taken seriously. In 2019, the Quebec ${ }^{135}$ Court of Appeal rendered the decision

${ }^{131}$ Article 156 a of the Indonesian Penal Code reads, “. commits an act. which principally have the character of being at enmity with, abusing or staining a religion, adhered to in Indonesia.

132 'Penggagas Sholat Bahasa Indonesia Divonis 2 Tahun Penjara, Hidayatullah' [The Creator of Prayers in Indonesian Sentenced to 2 Years in Prison, Hidayatullah]' (30 August, 2005) <https:// www.hidayatullah.com/berita/nasional/read/2005/08/30/40984/penggagas-sholat-bahasa-indonesia-divonis-2-tahun-penjara.html $>$ accessed 1 July 2020.[translated from Indonesian by Sébastien Lafrance].

${ }^{133}$ Tempo, 'Mengapa Tak Boleh Ada Aplikasi Alkitab Bahasa Minang Di Indonesia Yang Beragam?' [Why Is There No Various Indonesian Minang Bible Applications in Indonesia?]' (12 June, 2020) <https://www.tempo.co/abc/5674/mengapa-tak-boleh-ada-aplikasi-alkitab-bahasaminang-di-indonesia-yang-beragam $>$ accessed 30 June 2020.[translated from Indonesian by Sébastien Lafrance].

134 ibid.

${ }^{135}$ Quebec is a predominantly French-speaking province in eastern Canada. 
Ward c. Commission des droits de la personne et des droits de la jeunesse $e^{136}$ (Gabriel et autres) [hereinafter 'Ward'], ${ }^{137}$ which will be heard by the Supreme Court of Canada. This case attracted substantial media coverage. In his stand-up routine, comedian Mike Ward made a number of comments relating to physical characteristics of a young man who had become famous by singing for well-known public figures. ${ }^{138}$ This young man suffers from Treacher Collins Syndrome. ${ }^{139}$

Linda Pahuta remarked, "What we laugh at and when we laugh reveals so much about a society and social relations". ${ }^{140}$ What makes the Ward case interesting in light of freedom of expression is that this stand-up comedian argued on appeal that "the disputes raised important questions concerning the scope of freedom of expression in the artistic field". ${ }^{141}$ The majority of the Quebec Court of Appeal held that the finding of discrimination against that young man was reasonable. The dissenting judge concluded otherwise, "[d]espite their shocking and derogatory nature, [Mike Ward's] remarks did not convey discriminatory speech. ${ }^{142}$ As recalled by Maxime St-Hilaire and Chantal Bellavance, "freedom of expression includes that of artistic expression, in practice it accepts the thesis that this freedom may have to give way to other rights such as ... the right to non-discrimination" 143 even if "the freedom of expression is quite literally a "fundamental freedom". ${ }^{144}$

${ }^{136}$ In English, Human Rights Commission.

${ }^{137}$ Ward c Commission des droits de la personne et des droits de la jeunesse (Gabriel et autres) [hereinafter 'Ward'], 2019 QCCA 2042, leave to appeal to the Supreme Court of Canada was granted (as of July 30, 2020).

138 ibid.[para 12] (dissenting opinion).

139 ibid.[para 10].

${ }^{140}$ Lida Pahuta, 'The Limitations of Ethnic Humour: Can Ethnic Humour Function as an Anti-Racist Discourse? Master of Arts' (University of Toronto 2004).

${ }^{141}$ Ward c. Commission des droits de la personne et des droits de la jeunesse (Gabriel et autres) [hereinafter 'Ward'], 2019 QCCA 2042, leave to appeal to the Supreme Court of Canada was granted (as of July 30, 2020) (n 137). [para 34] (dissenting opinion) [translated from French by Sébastien Lafrance].

${ }^{142}$ ibid,[para 8] (dissenting opinion) [translated from French by Sébastien Lafrance].

${ }^{143}$ Maxime St-Hilaire and Chantal Bellavance, 'La Critique d'appropriation Culturelle: Nouvel Iconoclasme' [Criticizing Cultural Appropriation: New Iconoclasm]' (2019) 132 Revue Inter.[9]. [translated from French by Sébastien Lafrance]; see also Ward c. Commission des droits de la personne et des droits de la jeunesse (Gabriel et autres) [hereinafter 'Ward'], 2019 QCCA 2042, leave to appeal to the Supreme Court of Canada was granted (as of July 30, 2020) (n 137). [para 114].

${ }^{144}$ Kent Roach and David Schneiderman (n 26).[429]. 
Richard Moon wrote,"The courts support the restriction of "extreme" expression or expression that "goes too far". ${ }^{45}$ Coincidentally, the majority of the Quebec Court of Appeal qualified the impugned comments in the exact same way, "This time he went too far". ${ }^{146}$ Was it a moral judgment made by this court? It must be noted here that "[ $[\mathrm{t}]$ he Canadian constitutional case law is marked by a wise assumption that judicial practice must abstain from imposing ambiguous and moralising rules in law". ${ }^{147}$ The majority of the Quebec Court of Appeal recalled, "artistic freedom is not absolute" 148 and wrote that "[ $t]$ he line between limiting freedom of expression in the name of dignity and censorship is thin". ${ }^{149}$ An author also explained, "censorship is justified when an individual seeks to use language to deceive his/her audience or in circumstances where the audience has little opportunity to judge the truth of the statements made before they take action". ${ }^{150}$ But did the conclusion of the majority of the Quebec Court of Appeal censor the impugned comments because it must be kept in mind that, in fact, they did not deceive anybody and" [t]he reasonable person certainly does not expect, in a comedy show, that a stand-up comedian only utters truthful words?". ${ }^{151}$

${ }^{145}$ Richard Moon, 'Freedom of Expression and the Canadian Charter of Rights' (2002) 21 Windsor YB Access Just.[563, 565].

${ }^{146}$ Ward c. Commission des droits de la personne et des droits de la jeunesse (Gabriel et autres) [hereinafter 'Ward'], 2019 QCCA 2042, leave to appeal to the Supreme Court of Canada was granted (as of July 30, 2020) (n 137). [para 209] in fine [translated from French by Sébastien Lafrance].

${ }^{147}$ Marcin Górski, 'Freedom of Artistic Expression: Constitutional Lessons from Canada' (2017) 145 ELTE LJ.[145]; When it comes to criminal law, "Two criteria govern the incrimination of mockery: the seriousness and the wickedness of the humour in question.": Pierre Rainville, 'Paroles de Déraison et Paroles de Dérision: Les Excès de Langage à l'épreuve Du Droit Criminel Canadien' [Words of Insanity and Words of Derision: Excessive Language in the Face of Canadian Criminal Law]' (2015) 49-1 Revue juridique Thémis.[62]. [translated from French by Sébastien Lafrance].

${ }^{148}$ Ward c. Commission des droits de la personne et des droits de la jeunesse (Gabriel et autres) [hereinafter 'Ward'], 2019 QCCA 2042, leave to appeal to the Supreme Court of Canada was granted (as of July 30, 2020) (n 137).[para 209]. [translated from French by Sébastien Lafrance].

149 ibid.[para 203] [translated from French by Sébastien Lafrance].

${ }^{150}$ Richard Moon, 'Lifestyle Advertising and Classical Freedom of Expression Doctrine' (n 89). [80]; see also 83: 'J.S. Mill in On Liberty' argues that censorship inhibits the progress of human knowledge for two general reasons. First, no one is infallible, especially not the state".

${ }^{151}$ Ward c. Commission des droits de la personne et des droits de la jeunesse (Gabriel et autres) [hereinafter 'Ward'], 2019 QCCA 2042, leave to appeal to the Supreme Court of Canada was granted (as of July 30, 2020) (n 137). [para 129] (dissenting opinion) [translated from French by Sébastien Lafrance]. 
Historically, "The clowns [take] advantage of freedom of speech, with access to the nobility and a hierarchical awareness". ${ }^{152}$ In the Ward case, the young man who suffers from Treacher Collins Syndrome may be considered to be at the other end of the social hierarchy, he is vulnerable, mostly because of his health condition. Therefore, the question that deserves to be asked is: when will a restriction on freedom of expression be "necessary in a democratic for the protection of others?"153 and "where and when do you draw the lines?". ${ }^{154}$ A possible answer to that mind-puzzling question could be eventually based on the following view, "not all speech is equal. Sometimes vitriolic speech silences those it targets, especially if they are vulnerable, with the result that far from promoting healthy democratic conversations, it results in promoting toxic monologues. On the other hand, I accept that some comments can be offensive without attracting a legal duty to refrain". ${ }^{155}$ That being said, on what objective basis could the comments made by this standup comedian be qualified as 'toxic' by a judge? Justice Rothstein, writing for a unanimous court, acknowledged in Saskatchewan (Human Rights Commission) v. Whatcott [hereinafter 'Whatcott'], the most recent 'hate speech' case decided by the Court, "As long as human beings act in the role of judge or arbitrator, there will be a subjective element in the application of any standard or test to a given fact situation" ${ }^{156}$ but it does not necessarily mean that their decision will be arbitrary. ${ }^{157}$ However, as the dissenting judge of the Quebec Court of Appeal mentioned in the Ward case, "it is not for the courts to act as an adjudicator in matters of courtesy, politeness or good taste". ${ }^{158}$ Justice Rothstein commented on humour and the

${ }^{152}$ Naoko Ishikawa, 'The English Clown: Print in Performance and Performance in Print' (University of Birmingham 2011).[221].

${ }^{153}$ Denise Meyerson, 'The Legitimate Extent of Freedom of Expression' (2002) 52 U Toronto LJ.[332].

${ }^{154}$ Rosalie Silberman Abella (n 22).[504].

${ }^{155}$ ibid.[508] .

156 Saskatchewan (Human Rights Commission) v Whatcott, [2013] I SCR 467.[para 33] (hereinafter 'Whatcott'); see also Shruti Bedi and Sébastien Lafrance (n 33).

${ }^{157}$ See e.g. Shruti Bedi and Sébastien Lafrance (n 33).ibid.

158 Ward c. Commission des droits de la personne et des droits de la jeunesse (Gabriel et autres) [hereinafter 'Ward'], 2019 QCCA 2042, leave to appeal to the Supreme Court of Canada was granted (as of July 30, 2020) (n 137).[para 6]. 
freedom of expression in Whatcott. He wrote: ${ }^{159}$

"Expression criticizing or creating humour at the expense of others can be derogatory to the extent of being repugnant. ... offensive ideas are not sufficient to ground a justification for infringing on freedom of expression....

There may be circumstances where expression that "ridicules" members of a protected group goes beyond humour or satire and risks exposing the person to detestation and vilification on the basis of a prohibited ground of discrimination. ...

Restricting expression because it may offend or hurt feelings does not give sufficient weight to the role expression plays in individual self-fulfillment, the search for truth, and unfettered political discourse".

Thus, sometimes humour crosses the line and becomes 'hate speech'. ${ }^{160}$

\section{ii. Hate Speech}

"Hatred is a strong word, for a powerful passion". ${ }^{161}$ Many countries in the world criminalized or otherwise regulated hate propaganda in their domestic laws. ${ }^{162}$ However, in contrast with Indonesia where, "[d]espite [a] wide definition, Indonesian police have rarely acted against perpetrators of hate speech", ${ }^{163}$ it is an offence that has been brought to the courts one more than one occasion in Canada, including recently. ${ }^{164}$ Whatcott is the last of a line of decisions that focused on

\footnotetext{
${ }^{159}$ Saskatchewan (Human Rights Commission) v. Whatcott, [2013] 1 SCR 467 (n 156).[para 90-91 and 109].

${ }^{160}$ See e.g. M'Bala M'Bala c. France (déc.) - 25239/13, European Court of Human Rights, Decision 20.10.2015, para 39: "The Court thus considered, like the court of appeal, that during the litigation, the evening had lost its characters as an entertainment show to become a meeting. The applicant cannot claim ... to have acted as an artist having the right to express himself through satire, humor and provocation. Indeed, under the cover of a humorous representation, he invited one of the best-known French Holocaust deniers, convicted a year earlier for challenging a crime against humanity, to honor him and give him the floor" [translated from French by Sébastien Lafrance].

${ }^{161}$ Arthur Fish, 'Hate Promotion and Freedom of Expression: Truth and Consequences' (1989) 2 Can JL \& Jurisprudence.[121].

${ }^{162}$ Kathleen E Mahoney, 'Hate Speech: Affirmation or Contradiction of Freedom of Expression' (1996) 789 U Ill L Rev.[803]: "Since 1992, Sweden, Belgium, Azerbaijan, Brazil, Cyprus, the Czech Republic, Austria, Italy, Estonia, Lithuania, New Zealand, Romania, Russia, Switzerland, Hungary, and the Netherlands".

163 ibid.

${ }^{164}$ R. v. Sears, 2019 ONCJ 104 (n 3).
} 
freedom of expression in the context of 'hate speech'. ${ }^{165} \mathrm{Mr}$. Whatcott published and distributed flyers that promoted hatred against individuals on the basis on their sexual orientation. In that decision, the court circumscribed the meaning of 'hatred' in that context, ${ }^{166}$

"... the legislative term "hatred" or "hatred or contempt" must be interpreted as being restricted to those extreme manifestations of the emotion described by the words "detestation" and "vilification". This filters out expression which, while repugnant and offensive, does not incite the level of abhorrence, delegitimization and rejection that risks causing discrimination or other harmful effects".

The Court maintained that hate speech "shuts down dialogue by making it difficult or impossible for members of the vulnerable group to respond, thereby stifling discourse". ${ }^{167}$ It "rejected the suggestion that hate speech laws should require proof of a clause causal connection between speech and harm". ${ }^{168}$ John Stuart Mill with whom the Court has a lot in common when it comes to interpreting the freedom of expression is of the view that "not all opinions are immune from proscription. The liberty of the individual may be circumscribed when his opinions are 'a positive instigation to some mischievous act". ${ }^{169}$ Instigation to such acts seems to be sufficient in that regard. This decision provides an example of how the freedom of expression may be limited, and that 'hate speech' is excluded from the constitutional protection of that freedom. In other words, it reminds us that in Canada, freedom of expression is not absolute.

iii. Language Expression

As the Court put it, "The importance of language rights is grounded in the essential role that language plays in human existence, development and dignity". ${ }^{170}$

${ }^{165}$ R. v. Zundel, [1992] 2 SCR 731 (n 72) ; R. v. Keegstra, [1990] 3 SCR 697 (n 93); Canada (Human Rights Commission) v Taylor, [1990] 3 SCR 892; Rv Andrews, [1990] 3 SCR 870.

${ }^{166}$ Saskatchewan (Human Rights Commission) v. Whatcott, [2013] 1 SCR 467 (n 156).[para 57].

167 ibid.[para 117].

${ }^{168}$ Rosalie Silberman Abella (n 22).[518].

169 John Stuart Mill, 'On Liberty' 1859 [67-68].; Thomas David Jones, 'Human Rights: Freedom of Expression and Group Defamation under British, Canadian, Indian, Nigerian and United States Law - A Comparative Analysis' (1995) 18 Suffolk Transnat'l L Rev.[486].

${ }^{170}$ Reference re Manitoba Language Rights, [1985] 1 SCR 721.[744]; see also Shruti Bedi and Sébastien Lafrance, 'The Linguistic Diversity of Pluralist Cultures: Comparing the Status of Linguistic Minorities in India and Canada' in Santoshi Haldar (ed), Diversity and Inclusion: Designing and Implementing Inclusive Education in International Contexts (Springer International 2021). 
In a blunt statement, an author wrote, "All the world knows that the English and the French have had difficulty co-existing throughout modern history". ${ }^{171}$ Things changed since then. Canada is officially a bilingual state ${ }^{172}$ but not to "the sense that all Canadians do or must speak two languages". ${ }^{173}$ However, "At present, language laws in Quebec now generally allow the use of languages other than French, so long as the French language is predominant". ${ }^{174}$ The language issue in Canada goes in contrast with Indonesia, at least historically, for example with the Youth Pledge of 1928, known as Sumpah Pemuda, that provided a "pledge to uphold one unifying language, the Indonesian language". ${ }^{175}$

Leslie Green noted, "[e]ven if medium is distinct from message ... the Canadian constitution finds reasons for protecting both". ${ }^{176}$ Indeed, in Ford $v$. Quebec, the Court found, "language is so intimately related to the form and context of expression that there cannot be true freedom of expression by means of language if one is prohibited from using the language of one's choice. Language is not merely a means or medium of expression; it colors the content and meaning of expression". ${ }^{177}$

Throughout its history, "The French majority in Quebec wish to maintain the preeminence of French in that jurisdiction as a bulwark against the sea of English in the continent of North America". ${ }^{178}$ This did not happen without tensions and difficulties, ${ }^{179}$ then "restrictions on the form of expression have been especially important in Canada in the context of language choice". ${ }^{180}$ For example, "[i]n Devine

${ }^{171}$ Edward Veitch, 'Language, Culture and Freedom of Expression in Canada' (1990) 39 Int'1 \& Comp LQ. [101].

172 See e.g. Official Languages Act, R.S.C. 1985, c 31 (4th Supp).

${ }^{173}$ Edward Veitch (n 171). [109].

${ }^{174}$ Kent Roach and David Schneiderman (n 26).[441].

${ }^{175}$ Dwi Agus Yuliantoro, 'Contesting Visions of Indonesian National Identity' (Michigan State University 2016).[3].

${ }^{176}$ Leslie Green, 'Freedom of Expression and Choice of Language' (1991) 13 Law \& Pol'y. [220].

${ }^{177}$ Ford v. Quebec, [1988] 2 S.C.R. 712 (n 93).,[para 40].

${ }^{178}$ Edward Veitch (n 171).[109].

${ }^{179}$ See a famous example that encapsulates this issue with Reference re Secession of Quebec, [1998] 2 SCR 217.

${ }^{180}$ Kent Roach and David Schneiderman (n 26).[439]. 
v. Quebec, the Court held that the requirement for bilingual commercial documents was a proportionate and reasonable means to protect the French language. In Ford v. Quebec, however, the Court held that a total ban on the use of languages other than French in commercial signs was not a proportionate restriction on freedom of expression". ${ }^{181}$

V. Reasonable Limitation to Freedom of Expression

A. Indonesia

Freedom of expression is subject to certain limitations, mainly pursuant to Article 28J(2) of the 1945 Constitution. It reads: "In exercising their rights and freedoms, every person is obliged to submit to limitations set forth in the law with the sole purpose is to guarantee the recognition and respect for the rights and freedoms of others and to meet fair demands in accordance with moral considerations, religious values, security and public order in a democratic society". In addition, restrictions to fundamental rights also appear in Law No. 39 of 1999 Concerning Human Rights under Article 73, which provides, "The rights and freedoms governed by the provisions set forth in this Act may be limited only by and based on law, solely for the purposes of guaranteeing recognition and respect for the basic rights and freedoms of another person, fulfilling moral requirements, or in the public interest". In addition to this Article, Article 74 serves as an interpretative clause of the "Limitations and Prohibitions".

In Indonesia, the expression of political discourse, such as the right to selfdetermination, has often been disregarded by law enforcers. Although political expression should be considered as a protected form of expression, it is not always applied by the book by the State. In fact, political expression has, in some cases, rather been considered to be the equivalent of expressing the will of insurgents, separatists, or of those wanting to dissolve the country, for example in the case of Papuans; Papua being the largest and easternmost province of Indonesia that is populated by a high number of Indigenous people. In 2019 and 2020, there were

${ }^{181}$ ibid.[440]. 
120 Papuan activists and civilians, who were jailed for treason with the aim of separating from the unitary State of Indonesia. Based on the documents obtained by the media Tempo, the identity of 109 political prisoners is still unknown. The National Human Rights Commission (NHRC) also reported data from the years 2015-2018 where they found that 42 people were killed, and 93 people were injured due to human rights violations in Papua. NHRC also found 43 people were arrested for treason or insurgency charges. ${ }^{182}$

The Indonesian Constitutional Court warned and asked the authorities in the seminal decision No. 7/PUUXV/2017 to be more cautious when using 'treason' or 'insurgency' (makar) offenses in cases involving freedom of expression. Law enforcement should be careful to not let these offenses become a tool to silence freedom of expression in a democratic country where democracy is one of the pillars of the 1945 Constitution. ${ }^{183}$ In that decision, the court found that 'treason' or 'insurgency' offenses have often been misapplied, wrongfully used and misinterpreted by public prosecutors and judges. The interpretation and application of these offences were limited to an element of 'intention' (mens rea) without an 'act' (actus reus) when it should involve both. Putting Indonesian citizens in jail simply because they exercised their freedom of expression, for example by raising the Papua's Morning Star flag is illegitimate and is contrary to human rights law. Unfortunately, the warnings of the Indonesian Constitutional Court in that 2017 decision were not applied, again and more recently in 2020, by the judges in the Jakarta District Court ${ }^{184}$ and the Balikpapan District Court. ${ }^{185}$ Therefore, law

${ }^{182}$ Tempo, 'Dua Tahun Terakhir, 120 Warga Papua Dipenjara Atas Tuduhan Makar' [In the Last Two Years, 120 Papuans Imprisoned for Makar Allegations]' (10 June, 2020) < https://nasional. tempo.co/read/1351718/dua-tahun-terakhir-120-warga-papua-dipenjara-atas-tuduhan-makar/ full\&view $=$ ok $>$ accessed 25 June 2020.

${ }^{183}$ Indonesian Constitutional Court Decision Number 7/PUU-XV/2017.[157].

${ }^{184}$ Govt Ind v Paulus Suryanta Ginting Surya, Ambrosius Mulait, Issay Wenda, dan Charles Kossay (1303/PidB/2019/PNJktPst); Govt Ind v Dano Anes Tabuni (1304/PidB/2019/PNJktPst) and Govt Ind v Ariana Elopere (1305/PidB/2019/PNJkt/Pst). The court decisions were rendered on 24 April 2020.

${ }^{185}$ Govt Ind v Buchtar Tabuni; Govt Ind v Irwanus Uropmabin, Alexander Gobay, Hengki Hilapok, Fery Kombo Stevanus Itlay alias Steven Itlay, and Agus Kossay. The court decisions were rendered on 17 June 2020. 
enforcement not only showed inconsistency with was decided by the Indonesian Constitution Court in 2017 when addressing the Papuan cases, but they also perpetuated a 'persistent legal uncertainty'.

B. Canada

One of the reasons why the freedom of expression is so broadly interpreted in Canada is "because the Court can and does make contextual distinctions between different forms of expression under [the limitation clause]". ${ }^{186}$ However, Peter Hogg observed, ${ }^{187}$

"The broader the scope of the rights guaranteed by the Charter, the more relaxed the standard of justification must be. The narrower the scope of rights, the more stringent the standard of justification must be. It is not possible to insist that the Charter rights should be given a generous interpretation, that is, wide in scope, and at the same time insist that the standard of justification under section 1 should be a stringent one. One of these two contradictory positions must give way".

Also, as pointed out by Grant Huscroft, "The real scope of the freedom of expression emerges only following consideration of section 1 of the Charter". ${ }^{188}$ Indeed, "[m]ost cases"189 where freedom of expression is at issue are decided - with the exception of violent activities - under section 1 of the Charter, which is the limitation clause that determine if a restriction to a right or a freedom is reasonable 'in a free and democratic society'. As Hin-Yan Liu describes it summarily, "The definitive test of this provision is in $\mathrm{R} v$ Oakes, comprising of two limbs: there must be a 'pressing and substantial objective'; and the means must be 'proportional', requiring that these means to be 'rationally connected to the objective', that there must be a 'minimal impairment of the rights', and that there must be proportionality between the infringement and the objective". ${ }^{190}$ It is also important to note that "[t]he application of the Oakes test in freedom of expression cases has evolved

\footnotetext{
${ }^{186}$ Kent Roach and David Schneiderman (n 26).[439].

${ }^{187}$ Peter W Hogg, 'Interpreting the Charter of Rights: Generosity and Justification' 28 Osgoode Hall U.[819].

${ }^{188}$ Grant Huscroft (n 33).[186].

${ }^{189}$ Robin Elliot (n 92).[210].

${ }^{190}$ Hin-Yan Liu (n 61).[12]; see also R. v. Oakes, [1986] 1 S.C.R. 103, which created what is called the "Oakes test" in Canadian constitutional law. (n 64).
} 
in its own distinct way compared to other Charter rights". ${ }^{191}$ Ironically, for a nonCanadian legal audience, but also... for a Canadian legal audience, let's not forget that "[t]his analysis [is] sometimes difficult to understand and to apply". ${ }^{92}$

In spite of its complexity, the Oakes test does not seem to be sophisticated enough to "resolve the issue of the interrelationship of freedom of expression and other values of importance in our society", ${ }^{193}$ for example in the cases where this freedom comes into opposition with the dignity, the reputation, etc., of others; it then becomes a "conceptual battle of ... constitutional titans"194

As for Indonesia, an example of how the limitation clause was applied to the freedom of expression is provided by Simon Butt: ${ }^{195}$

"[An] example of the Court applying Article 28J(2) is the Pornography Law case (2009). Here, the Court upheld provisions of the 2008 Pornography Law which banned producing, reproducing and distributing a wide range of 'offensive' material, conservatively defined ... The Court held that the 2008 Pornography Law legitimately restricted the constitutional freedoms of speech and expression because it sought to protect Indonesia-wide community 'values of propriety' (nilai-nilai kesusilaan)".

The pornography controversial ${ }^{196}$ issue was also scrutinized more than once by the Court in light of the freedom of expression. ${ }^{197}$ Simon Butt commented further about the Indonesian Pornography Law case, 2009. He wrote: ${ }^{198}$

"Courts around the world are, of course, required to balance rights and interests against each other in constitutional review cases. Many do so by applying 'proportionality' tests. However, the Indonesian Constitutional Court appears

${ }^{191}$ Elizabeth L. McNaughton and Christopher M. Goodridge (n 27).[528].

${ }^{192}$ William A. Schabas and Daniel Turp, 'La Charte Canadienne Des Droits et Libertés et Le Droit International: Les Enseignements de La Cour Suprême Du Canada Dans Les Affaires Keegstra, Andrews et Taylor" [Canadian Charter of Rights and Freedoms and International Law: Teachings of the Supreme C' (1989) 6 Revue québécoise de droit int'1.[15]. [translated from French by Sébastien Lafrance].

${ }^{193}$ Clare F Beckton (n 96).[585].

${ }^{194}$ Rosalie Silberman Abella (n 22).[508].

${ }^{195}$ Simon Butt, The Constitutional Court and Democracy in Indonesia (2015) (n 14).[85].

${ }^{196}$ Patrick J. Monahan, 'The Supreme Court of Canada in the 21st Century' (2001) 80 Can. B. Rev.[376]: "[t]he Charter requires the courts to scrutinize the work of legislatures and governments in a wide variety of contested and controversial policy areas".

${ }^{197}$ On pornography in general, see e.g. $R v$ Butler, [1992] 1 SCR 452., and on child pornography see e.g. $R v$ Sharpe, [2001] 1 SCR 45.

${ }^{198}$ Simon Butt, The Constitutional Court and Democracy in Indonesia (2015) (n 14).[85-86] (italics added). 
to have gone further than courts in other countries with enforceable bills of rights, allowing legislation that limits or even ignores constitutional rights that are expressly non-derogable".

While the Supreme Court of Canada may not have gone 'as far' as the Indonesian Constitutional Court in cases involving pornography in Canada, we should not exclude the possibility that the Supreme Court of Canada may have departed from a standard application of the limitation clause, at least according to some commentators. Indeed, it may just have happened in other cases involving rights and freedoms different than the freedom of expression. For example, regarding the recent case Frank v. Canada (Attorney General), ${ }^{199}$ which called into question "one of the last restrictions on the right to vote in federal elections", ${ }^{200}$ i.e. the residence, Sonja C. Grover observed with respect to the questionable application by the majority of the of the limitation clause: "The Majority Justices ... never articulated ... why s. 1 of the Charter uses the term "limit" and why it is permissible or advisable, on the Majority view, to substitute for the existing s. 1 Charter text the term "infringement". ${ }^{201}$

\section{Conclusion}

This article has shown that despite having similarities when it comes to multiculturalism, in practice, the development of the recognition of freedom of expression through the operation of different laws may be different in Indonesia and Canada. In Indonesia, the religion-based pressure factor plays a more important role, and may even have an influence on judicial decisions. The approach to the issue of violence when dealing with Papuans with the narrative of the Unitary State of the Republic of Indonesia remained "undisputed". The authors submit that this approach

\footnotetext{
${ }^{199}$ Frank v Canada (Attorney General), [2019] 1 SCR 3.

${ }^{200}$ ibid.[para 3].

${ }^{201}$ Sonja C. Grover, Judicial Activism and the Democratic Rule of Law: Selected Case Studies (Springer Nature 2020).[139]; Frank v. Canada (Attorney General), [2019] 1 SCR 3 (n 199). [para 122] (Côté and Brown JJ., dissenting opinion): “The majority's response ... is, in our respectful view, internally inconsistent. ... it sees the matter as being of sufficient importance to insist upon departing from the text of s. 1."
} 
institutionalized discrimination which, in turn, also impacted on the exercise of freedom of expression in Indonesia. There are many cases of political prisoners whose actions were criminalized for alleged treason. As for other types of cases, like Ahok's and Meliana's cases, it also showed a politicization of law enforcement that is organized and mobilized by those who have an interest in political networks.

While in Canada, the meaning of multiculturalism underwent an evolution that did not include pressure based on religion on freedom of expression, the judicial system in Canada spent instead lots of efforts to support, in compliance with the rule of law and democratic principles, the protection afforded by the freedom of expression in a way that strengthened the ties of a multicultural society.

Learning from the exercise that consisted in this paper to compare relevant laws of two countries, and despite the differences between their respective legal traditions, this study focused on showing that a legal concept that is identical in the abstract, here the freedom of expression, in two different countries such as Indonesia and Canada, can play a more effective role in a society with a multicultural character that complies with the rule of law.Far from being a comparison between oranges and apples, the authors hope that this paper rather leaves food for thought in terms of the interests triggered by the comparison between Indonesian and Canadian constitutional law, more specifically in light of freedom of expression, as it is delineated by their respective principles, and as it is applied by the courts of each country. While there are obvious differences between Indonesia and Canada, there are also many similarities, for example when this freedom comes into play, that make the study of this freedom in both these countries a promising avenue for the researchers.

\section{Bibliography}

Adriaan Bedner, Administrative Courts in Indonesia: A Socio-Legal Study (Martinus Nijhoff 2001).

— , 'An Elementary Approach to the Rule of Law' (2010) 2 Hague Journal on the Rule of Law.

Adrienne Stone, The Comparative Constitutional Law of Freedom of Expression' 
in Tom Ginsburg and Rosalind Dixon (Eds), Comparative Constitutional Law (Edward Elgar Publishing 2011).

Alan Borovoy, Kathleen Mahoney BB and JC, 'Language As Violence v. Freedom of Expression: Canadian and American Perspectives on Group Defamation' (1988) 37 Buff L Rev.

Alan C. Cairns, Citizens Plus and the Canadian State (UBC Press 2000).

'Also Provided by Article 29 of the Constitution of the Republic of Indonesia (Last Amended 2002) [Hereinafter "Indonesian Constitution"]' (1945) <https:// www.refworld.org/docid/46af43f12.html> accessed 19 May 2020.

Amalinda Savirani, Post-Election Politics in Indonesia: Between Economic Growth and Increased Islamic Conservatism' in Southeast Asian Affairs (Malcolm Cook and Daljit Singh ed, 2020).

Article 156 a of the Indonesian Penal Code reads, ". commits an act. which principally have the character of being at enmity with, abusing or staining a religion, adhered to in Indonesia.

Article 28J(2) of the Indonesian Constitution.

Arthur Fish, 'Hate Promotion and Freedom of Expression: Truth and Consequences' (1989) 2 Can JL \& Jurisprudence.

Benjamin Oliphant, 'Freedom of the Press as a Discrete Constitutional Guarantee' (2014) 59-2 McGill Law Journal.

Bisariyadi, 'Atypical Rulings of the Indonesian Constitutional Court' (2016) 2 Hasanuddin Law Review

Canada (Human Rights Commission) v Taylor, [1990] 3 SCR 892.

Canadian Charter of Rights and Freedoms, Part I of the Constitution Act, 1982, being Schedule B to the Canada Act, 1982 (UK), 1982 cl [hereinafter 'Charter'].

'Canada Population' (2020) $<$ https://worldpopulationreview.com/countries/canadapopulation $>$ accessed 18 May 2020.

Canadian Broadcasting Corporation (CBC), 'Trudeau Apologizes for "Colonial," "Purposeful" Mistreatment of Inuit with Tuberculosis' (March 8, 2019) $<$ https://www.cbc.ca/news/canada/north/trudeau-apology-tuberculosisiqaluit-1.5047805.>. 
Caroline Reid, 'Freedom of Expression, Commercial Expression and Tobacco in Canada' (2008) 39 Victoria U Wellington L Rev.

Centre for Research and Information on Canada, The Charter: Dividing or Uniting Canadians? (2003).

Chanakya Sethi, 'Beyond Irwin Toy: A New Approach to Freedom of Expression under the Charter' (2012) 17 Appeal: Rev Current L \& L Reform.

Cherian George, Hate Spin: The Manufacture of Religious Offense and Its Threat to Democracy (MIT Press 2016).

Clare F Beckton, 'Freedom of Expression in Canada - How Free' (1983) 13 Man LJ.

Constitutional Court Decision 99/PUU-X/2012 reviewing Law No 12 of 1992 on the Horticulture System.

Costantinus Fatlolon, 'Pancasila Democracy and the Play of the Good' (2016) 3 Filocracia.

Daniel Mockle, 'La Justice Constitutionnelle Face Au Mouvement Conservateur: La Cour Suprême Du Canada et Le Gouvernement Harper (2006-2015)' [Constitutional Justice Facing the Conservative Movement: The Supreme Court of Canada and the Harper Government] (2017) 58 C. De'.

Denise Meyerson, ‘The Legitimate Extent of Freedom of Expression' (2002) 52 U Toronto LJ.

Dominique Clement Will Silver and Dr. Daniel Trottier, 'The Evolution of Human Rights in Canada' (2012).

Dwi Agus Yuliantoro, 'Contesting Visions of Indonesian National Identity' (Michigan State University 2016).

Edward Veitch, 'Language, Culture and Freedom of Expression in Canada' (1990) 39 Int'l \& Comp LQ.

Edmonton Journal v Alberta (Attorney General), [1989] 2 SCR 1326, 1336.

Enacted by Law 5/1969 on Statements of Various Presidential Assignments and Presidential Regulations.

Elizabeth L. McNaughton and Christopher M. Goodridge, 'The Canadian Approach to Freedom of Expression and the Regulation of Food and Drug Advertising' (2003) 58 Food \& Drug LJ. 
Erik S Knutsen, 'Techno-Neutrality of Freedom of Expression in New Media beyond the Internet: Solutions for the United States and Canada' (2001) 8 UCLA Ent L Rev.

François Boucher, 'Deep Diversity and Multinational Federalism in Canada', Students' Best Papers, Summer University, Institute of Federalism, Fribourg, Switzerland' (2008) <https://www.academia.edu/6780444/Deep_diversity_ and_multinational_federalism_in_Canada $>$ accessed 19 May 2020.

Ford v Quebec, [1988] 2 SCR 712.

Frank v Canada (Attorney General), [2019] 1 SCR 3.

Gary F. Bell, 'Multiculturalism in Law Is Legal Pluralism - Lessons from Indonesia, Singapore and Canada' [2006] Singapore Journal of Legal Studies.

Grant Huscroft, 'The Constitutional and Cultural Underpinnings ofFreedom of Expression: Lessons from the United States and Canada' (2006) 25 U Queensland LJ.

Gunter Frankenberg, 'Critical Comparisons Re-Thinking Comparative Law' (1985) 26 Harv. Int’1 L.J.

Govt Ind v Ariana Elopere (1305/PidB/2019/PNJkt/Pst).

Govt Ind v Dano Anes Tabuni (1304/PidB/2019/PNJktPst).

Govt Ind v Paulus Suryanta Ginting Surya, Ambrosius Mulait, Issay Wenda, dan Charles Kossay (1303/PidB/2019/PNJktPst).

Govt Ind v Buchtar Tabuni; Govt Ind v Irwanus Uropmabin, Alexander Gobay, Hengki Hilapok, Fery Kombo Stevanus Itlay alias Steven Itlay, and Agus Kossay.

HendriYulius, 'WhenBooks BecomeThreats: Preserving "PublicOrder"in Indonesia, Indonesia at Melbourne' (May 23, 2016) <https://indonesiaatmelbourne. unimelb.edu.au/when-books-become-threats-preserving-public-order-inindonesia $>$ accessed 30 June 2020.

Herlambang P. Wiratraman, 'Press Freedom, Law and Politics in Indonesia: A Socio-Legal Study’ (Leiden University 2004).

__ 'Kebebasan Bereskpresi: Penelusuran Pemikiran Dalam Konstitusi Indonesia' (2009) 6 Jurnal Konstitusi.

— ' 'In Search of Constitutionality: Freedom of Expression and Indonesia's Anti Pornography Law' (2012) 20 Yuridika. 
—, Press Freedom, Law and Politics in Indonesia. A Socio-Legal Study (EM Meijers Institute, Wohrmann 2014).

- 'Does the Revised IT Law Guarantee More Freedom?' (The Jakarta Post, November 24, 2016) <https://www.thejakartapost.com/academia/2016/11/24/ does-the-revised-it-law-guarantee-more-freedom.html> accessed 27 May 2020.

—-, 'Kebebasan Akademik, Neo-Feodalisme Dan Penindasan HAM' in Al Khanif \& Manunggal (ed), Hak Asasi Manusia: Politik, Hukum dan Agama di Indonesia (LKIS 2018).

- ' 'Freedom of Expression, Law and Politics in Indonesia' in Azmi Sharom and Magdalen Spooner (ed), Human Rights and Democracy in Indonesia and Malaysia (SIRDC and SEAHRN 2019).

—-, 'Does Indonesian COVID-19 Emergency Law Secure Rule of Law and Human Rights?' (2020) 4 Journal of Southeast Asian Human Rights.

Hill v Church of Scientology of Toronto, [1995] 2 SCR 1130.

Hunter et al v Southam Inc, [1984] 2 SCR 145, 155-156.

Hin-Yan Liu, 'The Constitutional Right to Express Hatred: AComparative Analysis' (2009) 1 King's Student Law Review.

Ind Govt v AJI (Ahmad Taufik, Eko Maryadi, and Danang KW) (1995).

Ind Govt v Andi Syahputra (Suara Independen) (1996).

Ind Govt v Goei Po An (Terompet Masyarakat) (1951).

Indonesian Constitutional Court Decision Number 2/PUU-VII/2009, 5 May 2009.

Indonesian Constitutional Court Decision Number 7/PUU-XV/2017.

Irwin Toy Ltd v Quebec (Attorney General), [1989] 1 SCR 927.

Jaclyn L. Neo and Bui Ngoc Son, Pluralist Constitutions in the Southeast Asian Content' in Jaclyn L. Neo and Bui Ngoc Son (Eds), Pluralist Constitutions in Southeast Asia (Hart Publishing 2019).

Jacob Weinrib, 'What Is the Purpose of Freedom of Expression?' (2009) $67 \mathrm{U}$ Toronto Fac L Rev.

Javier Martínez-Torrón and W. Cole Durham, 'Religion and the Secular State' in 
Karen B. Brown and David V. Snyder (ed), General Reports of the XVIIIth Congress of the International Academy of Comparative Law (Springer 2012).

Jean Leclair, 'Canada's Unfathomable Unwritten Constitutional Principles' (2002) 27 Queen's L.J.

John M. Evans, 'Current Constitutional Issues in Canada' (2013) 51 Duq. L. Rev.

John Stuart Mill, 'On Liberty’ 185967.

Julian Walker, 'Hate Speech and Freedom of Expression: Legal Boundaries in Canada, Legal and Social Affairs Division, Parliamentary Information and Research Service' Publication No. 2018-25-E (29 June 2018).

Julius H. Grey, 'Freedom of Expression in a Canadian University Context' (1995) 44 U.N.B.L.J.

Kabir Duggal and Shreyas Sridhar, 'Reconciling Freedom of Expression and Flag Desecration: A Comparative Study' (2006) 2 Hanse L Rev.

Kathleen E Mahoney, 'Hate Speech: Affirmation or Contradiction of Freedom of Expression’ (1996) 789 U Ill L Rev.

Kathleen Harris, 'Liberal MP's Anti-Islamophobia Motion Set for Debate on Wednesday' (February 9, 2019) <https://www.cbc.ca/news/politics/m103islamophobia-khalid-motion-1.3972194 CBC News> accessed 18 May 2020.

Kent Roach and David Schneiderman, 'Freedom of Expression in Canada. Canadian Charter of Rights and Freedoms' (2013) 61 S.C.L.R. (2d).

Kompas, 'YLBHI: There Are Efforts to Mute Systematic Criticism' (15 June 2020) $<$ https://nasional.kompas.com/read/2020/06/15/20220211/ylbhi-ada-operpembamanaman-kritik systematically>.

- 'Kronologi Kasus Meiliana Yang Dipenjara Karena Keluhkan Pengeras Suara Azan' (23 August, 2018) <https://regional.kompas.com/ $\mathrm{read} / 2018 / 08 / 23 / 15053451 / \mathrm{kronologi}$-kasus-meiliana-yang-dipenjarakarena-keluhkan-pengeras-suara-azan> accessed 12 August 2020.

L.I. Nurtjahyo, 'Pembatasan Hak Kebebasan Berekpresi Berdasarkan Isu Ketertiban Umum: Kajian Atas Kovenan, Prinsip-Prinsip, Dan Produk Hukum Nasional', in Kebebasan Berekspresi di Indonesia - Hukum, Dinamika, Masalah, dan Tantangannya (Lembaga Studi dan Advokasi Masyarakat (ELSAM) 2019).

Leslie Green, 'Freedom of Expression and Choice of Language'(1991) 13 Law \& Pol'y. 
Lida Pahuta, 'The Limitations of Ethnic Humour: Can Ethnic Humour Function as an Anti-Racist Discourse? Master of Arts' (University of Toronto 2004).

Linda McKay-Panos, 'Universities and Freedom of Expression: When Should the Charter Apply’ (2016) 5 Can J Hum Rts.

Luc Huppé, Le Régime Juridique Du Pouvoir Judiciaire' [The Legal Regime of Judicial Power] (Wilson \& Lafleur 2000).

Marcin Górski, 'Freedom of Artistic Expression: Constitutional Lessons from Canada' (2017) 145 ELTE LJ.

Matteo Maciel, J.S. Mill on Hate Speech in the Canadian Context, vol IX (Minneapolis, Minnesota 2016).

Maxime St-Hilaire, "Are Quebec and Canada Having a "Schmittian" (or Iheringian) Moment?' (Int'l J. Const. L. Blog, May 6, 2020) <http://www.iconnectblog. com/2020/05/are-quebec-and-canada-having-a-schmittian-or-iheringianmoment $>$ accessed 18 May 2020.

Maxime St-Hilaire and Chantal Bellavance, 'La Critique d'appropriation Culturelle: Nouvel Iconoclasme' [Criticizing Cultural Appropriation: New Iconoclasm]' (2019) 132 Revue Inter.

Maya Hertig Randall, 'Freedom of Expression in the Internet' (2016) 26 Swiss Rev Int'l \& Eur L.

Martin Russell, Political Institutions in Indonesia: Democracy, decentralization, diversity, Briefing, January 20, 2020, 5.

Michael Marin, 'Should the Charter Apply to Universities?' (2015) 35:1 NJCL.

Michael Morfit, 'Pancasila: The Indonesian State Ideology According to the New Order Government' (1981) 21 Asian Survey.

Naoko Ishikawa, 'The English Clown: Print in Performance and Performance in Print' (University of Birmingham 2011).

Patrick J. Monahan, 'The Supreme Court of Canada in the 21st Century' (2001) 80 Can. B. Rev.

Patrick J. Monahan and Byron Shaw, Constitutional Law (4th edn, Irwin Law 2013).

'Penggagas Sholat Bahasa Indonesia Divonis 2 Tahun Penjara, Hidayatullah'

[The Creator of Prayers in Indonesian Sentenced to 2 Years in Prison, 
Hidayatullah]' (30 August, 2005) <https://www.hidayatullah.com/berita/ nasional/read/2005/08/30/40984/penggagas-sholat-bahasa-indonesiadivonis-2-tahun-penjara.html> accessed 1 July 2020.

Peter W Hogg, 'Interpreting the Charter of Rights: Generosity and Justification' 28 Osgoode Hall U.

Pierre-André Côté, The Interpretation of Legislation in Canada Translated and Revised by Steven Sacks (4th ed, Carswell 2011).

Pierre Rainville, 'Paroles de Déraison et Paroles de Dérision: Les Excès de Langage à l'épreuve Du Droit Criminel Canadien' [Words of Insanity and Words of Derision: Excessive Language in the Face of Canadian Criminal Law]' (2015) 49-1 Revue juridique Thémis.

Pranoto Iskandar, 'The Pancasila Delusion' (2016) 46 Journal of Contemporary Asia.

Prayekti Murharjanti, 'The Effectiveness of the Constitutionalisation of Environmental Rights in Indonesia: Judicial Application and Government Compliance' (University of Sydney, Australia 2019).

$R v$ Andrews, [1990] 3 SCR 870.

$R v$ Butler, [1992] 1 SCR 452.

$R v$ Keegstra, [1990] 3 SCR 697.

Rv Lucas, [1998] 1 SCR 439.

$R v$ Oakes, [1986] 1 SCR 103, which created what is called the "Oakes test" in Canadian constitutional law.

$R v$ Sears, 2019 ONCJ 104.

$R$ v Sharpe, [2001] 1 SCR 45.

$R v$ Therens, [1985] 1 SCR 613.

$R v$ Zundel, [1992] 2 SCR 731531.

R. David and J. Brierley, Major Legal System in the World Today (2nd ed, Free Press 1978).

R.J. Sharpe, 'Commercial Expression and the Charter' (1987) 37 U.T.L.J. 
Randall Peerenboom, 'Human Rights and Rule of Law: What's the Relationship' (2005) 36 Geo J Int'l L.

Redaksi dan FPI Sepakat Akhiri Kontroversi [Editorial Board and FPI Agree to End the Controversy], 3 February 2006.

Reference re Manitoba Language Rights, [1985] 1 SCR 721.

Reference re Secession of Quebec, [1998] 2 SCR 217.

Reference re ss 193 and 1951(1)(C) of the Criminal Code (Man), [1990] 1 SCR 1123.

RJR-MacDonald Inc v Canada (Attorney General), [1995] 3 SCR 199.

Richard Moon, 'Lifestyle Advertising and Classical Freedom of Expression Doctrine’ (1991) 36 McGill LJ.

— , 'Freedom of Expression and the Canadian Charter of Rights' (2002) 21 Windsor YB Access Just.

— , 'The Social Character of Freedom of Expression' (2009) 2 Amsterdam LF.

Roach K, In The Supreme Court on Trial: Judicial Activism or Democratic Dialogue (Irwin Law 2001).

Robert A Sedler, 'The Constitutional Protection of Freedom of Religion, Expression, and Association in Canada and the United States: A Comparative Analysis' (1988) 20 Case W Res J Int'1 L.

Robert J. Shape, 'The Supreme Court of Canada in Changing Times' (2003) August 27 Ontario Justice Education Network.

Robin Elliot, 'Back to Basics: 'A Critical Look at the Irwin Toy Framework for Freedom of Expression' (2011) 15 Rev Const Stud.

Rocket v Royal College of Dental Surgeons of Ontario, [1990] 2 SCR 232.

Rosalie Silberman Abella, 'Freedom of Expression or Freedom from Hate: A Canadian Perspective' (2018) 40 Cardozo L Rev.

Saskatchewan (Human Rights Commission) v Whatcott, [2013] 1 SCR 467.

Section 319(2) of the Criminal Code of Canada They were charged for and were found guilty of two counts of wilful promotion of hatred against an identifiable group - Jews and women. 
Switzman v Elbling and AG of Quebec, [1957] SCR 285.

Shruti Bedi and Sébastien Lafrance, The Justice in Judicial Activism: Jurisprudence of Rights and Freedoms in India and Canada' in Lokendra Malik and Prof. Yogesh P. Singh, Working of the Supreme Court of India: Issues and Challenges (Tentative Title) (Springer Publisher 2020).

- 'The Linguistic Diversity of Pluralist Cultures: Comparing the Status of Linguistic Minorities in India and Canada' in Santoshi Haldar (ed), Diversity and Inclusion: Designing and Implementing Inclusive Education in International Contexts (Springer International 2021).

Simon Butt, 'Islam, the State and the Constitutional Court in Indonesia' (2010) 19 Pacific Rim Law and Policy Journal.

— The Constitutional Court and Democracy in Indonesia (Brill 2015).

- 'The Indonesian Constitutional Court: Implying Rights from the "Rule of Law" in Rosalind Dixon, Adrienne Stone (Eds.)', The Invisible Constitution in Comparative Perspective (pp. 298-319) (Cambridge University Press 2018).

—-, 'The Indonesian Constitutional Court: Reconfiguring Decentralization for Better or Worse?' (2019) 14 Asian Journal of Comparative Law.

Sonja C. Grover, Judicial Activism and the Democratic Rule of Law: Selected Case Studies (Springer Nature 2020).

Syndicat Northcrest v Amselem, [2004] 2 SCR 551, para 50, recalled more recently by the same court, the Supreme Court of Canada, in Law Society of British Columbia v Trinity Western University, [2018] 2 SCR 293, para 333 (Côté and Brown JJ, dissenting.

Tempo, 'Dua Tahun Terakhir, 120 Warga Papua Dipenjara Atas Tuduhan Makar' [In the Last Two Years, 120 Papuans Imprisoned for Makar Allegations]' (10 June, 2020) <https://nasional.tempo.co/read/1351718/dua-tahun-terakhir120-warga-papua-dipenjara-atas-tuduhan-makar/full\&view $=$ ok $>$ accessed 25 June 2020.

, 'Mengapa Tak Boleh Ada Aplikasi Alkitab Bahasa Minang Di Indonesia Yang Beragam?' [Why Is There No Various Indonesian Minang Bible Applications in Indonesia?]' (12 June, 2020) <https://www.tempo.co/abc/5674/mengapatak-boleh-ada-aplikasi-alkitab-bahasa-minang-di-indonesia-yang-beragam> accessed 30 June 2020.

The plea was delivered by Teguh Santosa during the second court session, 6 
September 2006, in the South Jakarta District Court.

The Prohibition Letter No B/19811/XII/2015/Datro, signed by the Director of the Jakarta Metro Police Intelligence, Commissioner of Police, Suntana

Thomas David Jones, 'Human Rights: Freedom of Expression and Group Defamation under British, Canadian, Indian, Nigerian and United States Law - A Comparative Analysis' (1995) 18 Suffolk Transnat'1 L Rev.

Tim Lindsey and Simon Butt, Indonesian Law (Oxford University Press 2018).

Tirto, 'Jumlah Bahasa Daerah Di Indonesia Mencapai 652' (16 August 2018, 2018) $<$ https://tirto.id/jumlah-bahasa-daerah-di-indonesia-mencapai-652-pada2018-cSQY> accessed 20 August 2020.

_, 'Banjir Kasus Pasal Karet UU ITE Sepanjang 2019 [A Flood of ETI Cases Throughout 2019]' (27 December, 2019) <https://tirto.id/banjir-kasus-pasalkaret-uu-ite-sepanjang-2019-eo4V $>$ accessed 30 June 2020.

Troller v Manitoba Public Insurance Corporation, 2019 MBQB 157.

Troller v Manitoba Public Insurance Corporation.

Uladzislau Belavusau, 'Hate Speech', the Max Planck Encyclopedia of Comparative Constitutional Law (Oxford University Press 2017).

United Nations Human Rights - Office of the High Commissioner, 'COVID-19: Governments Must Promote and Protect Access to and Free Flow of Information during Pandemic - International Experts' (19 March 2020).

Ward c Commission des droits de la personne et des droits de la jeunesse (Gabriel et autres) [hereinafter 'Ward'], 2019 QCCA 2042, leave to appeal to the Supreme Court of Canada was granted (as of July 30, 2020).

William A. Schabas and Daniel Turp, 'La Charte Canadienne Des Droits et Libertés et Le Droit International: Les Enseignements de La Cour Suprême Du Canada Dans Les Affaires Keegstra, Andrews et Taylor" [Canadian Charter of Rights and Freedoms and International Law: Teachings of the Supreme C' (1989) 6 Revue québécoise de droit int'l.

HOW TO CITE: Herlambang P. Wiratraman and Sébastien Lafrance, 'Protecting Freedom of Expression in Multicultural Societies: Comparing Constitutionalism in Indonesia and Canada' (2021) 36 Yuridika.

This work was prepared separately from this author's employment responsibilities at the Public Prosecution Service of Canada. The views, opinions and conclusions expressed herein are personal to this author and should not be construed as those of the Public Prosecution Service of Canada or the Canadian federal Crown. 